\title{
4 The assembly of the land (zemskii sobor)
}

\section{Historiographies and mythologies of a Russian "parliament"1}

\author{
Ivan Sablin and Kuzma Kukushkin
}

\section{Introduction}

The term zemskii sobor ("the assembly of the land") was coined in the nineteenth century to refer to a number of different assemblies in the Tsardom of Russia. ${ }^{2}$ It was contested in the historiographies of early modern Russia, with the discussions revolving around the questions whether the individual instances of sobor ("assembly") and sovet ("council") in the sixteenth and seventeenth centuries could be seen as a coherent, albeit dynamic, institution; what constituencies (local and "social estate") were represented there; what role they played in the relations between the autocrat and his subjects; and how they could be compared to "parliaments" and other assemblies in premodern and early modern Europe and Asia. Most of contemporary authors agree that the zemskii sobor was not a coherent institution, and that it was not a "parliament" comparable to, for instance, the English Parliament or the Polish-Lithuanian Sejm ("assembly") of the time. The historiographic debates on the zemskii sobor had intertwined with myth-making since before the consolidation of the term. The zemskii sobor was used by both the opponents and the proponents of parliamentarism in Russia, nourishing both autocratic and democratic political mythologies. Furthermore, during the Revolution of 1905-1907, the Revolution of 1917, and the Civil War of 1918-1922, practical attempts were made to "reestablish" the institution. The Priamur Zemskii Sobor, which convened in Vladivostok in the summer of 1922, became the first assembly to bear such a name.

The current study charted the interpretations of the zemskii sobor in historiography and positioned the term in the autocratic and democratic mythologies of the nineteenth and early twentieth centuries. The historiographic debates on the zemskii sobor, be it a coherent institution or an umbrella term for disconnected assemblies, was stimulated by the lack of reliable sources on individual assemblies, which made the reconstruction of representation and proceedings impossible in many cases. When such reconstruction was possible, the situational representation of different localities and social groups at the assemblies, as well as the latter's irregularity and incoherence, pointed to the embeddedness of individual assemblies in the hierarchical imperial governance. The heterogeneity of the interactions between the monarch and his subjects, which could be categorized

DOI: $10.4324 / 9781003158608$ 
according to their social strata, locality, and position of service, contributed to the imagining of the zemskii sobor as an institution of pluralistic political representation in a dynamic composite society, that is, an imperial "parliament," even though there is no evidence that the historical sobors played such a role. At the same time, this heterogeneity also made the individual sobors part of the differentiated yet centralized imperial autocratic governance, built through heterogenous practices ${ }^{4}$ and hence a "non-parliament."

This study benefited from the Cambridge approach to intellectual history. When discussing historical texts, produced by Russian-language intellectuals and bureaucrats before 1922, it foregrounded the performative aspect of the term's use within concrete political circumstances and, following Quentin Skinner, understood the contextualized texts as political actions in the authors' pursuit of specific objectives rather than mere reflections. ${ }^{5}$ In this respect, this study defined political mythology as the narratives of the presumed phenomena of the past which were modified and applied to suit the political goals of the present. Given the chapter's focus on the nineteenth and early twentieth centuries, the mythologies of the zemskii sobor were studied against the backdrop of Russia's heterogeneous nationalist discourse in its multiple and intersecting romantic and civic aspects. ${ }^{6}$

The variety of the sobors in terms of their composition and genesis and the lack of factual information on the individual assemblies made the term zemskii sobor applicable for both autocratic and democratic mythologies. ${ }^{7}$ In the autocratic mythology, it represented the popular consensus behind God's anointed Romanov Tsars, referring to the 1613 "Zemskii sobor," which approved the new dynasty, ending the Time of Troubles (1598-1613). This interpretation was employed in the legitimation of the Romanov dynasty, including during the imperial crisis of the early twentieth century, and became an important component of romantic and pragmatic monarchist nationalism. In the democratic mythology, it was a historical Russian "parliament," or at least a precursor of one, which legitimized and constituted the Russian state. In this sense, the zemskii sobor was used for criticizing autocracy. If "reconvened," it was anticipated to become a modern constituent assembly, similar to the French National Constituent Assembly of 1789, or a modern parliament, and the concept was built into the different approaches to the Russian civic nation. Both mythologies, as well as their intersections, informed political imaginations and designs of the imperial and postimperial government. Given the intersections of ideas and the changing agendas of the authors, the division of the mythologies of the zemskii sobor into autocratic and democratic was schematic and based on the predominance of the Tsar or the people as the source of authority in the individual texts and on the extent of the proposed political changes.

\section{Historiographies}

The term zemskii sobor, denoting the assemblies in Russia of the sixteenth and seventeenth centuries, is a historiographic term. As such, it appeared in the $1850 \mathrm{~s}$, together with the systematic discussion of the presumed institution. The 
historiographic discussions of the nineteenth and early twentieth centuries were heavily influenced by the authors' political views, including on Russia's future. Over the course of the debates, however, more and more sources came to the knowledge of historians, providing the foundation for more neutral takes on the term and informing the contemporary historiographic discussion. The latter has unfolded since the second half of the twentieth century and featured direct polemics between Soviet and international authors in the 1980s. Since their beginning in the nineteenth century, the debates have revolved around the position of the sobors in the system of autocracy, the connections between the central government and localities (towns and provinces), and the existence or nonexistence of social estates in early modern Russia. There has been a growing consensus that the zemskii sobor was not a coherent institution, and some authors prefer not to use this term at all even when discussing the widespread process of consultation in early modern Russia. ${ }^{8}$

Historically, the word sobor was used for assemblies since the premodern period. It appeared in the ecclesiastical context in relation to Rus' already in the eleventh century. A text, dated to the 1030s-1050s and surviving in a fifteenthcentury version, for instance, mentioned Prince Vladimir getting advice from the bishops on legislative matters and compared him to the Byzantine Emperor Constantin the Great, who issued legislation with the Sobor of Nicaea. ${ }^{9}$ In the premodern chronicles, the term continued to be used for Christian assemblies. The Kievan Chronicle, dated to the twelfth century and surviving in a fifteenthcentury version, discussed the relations between a sobor and a prince, portraying the former as an institution which could pass judgment whether a particular action was considered sinful. ${ }^{10}$

The word sobor began to be used for the nonexclusively ecclesiastical assemblies since the middle of the sixteenth century, but the term zemskii sobor was not used for describing such assemblies in the sources. ${ }^{11}$ Ivan IV (later known as "the Terrible"), who was crowned the first Russian Tsar in 1547, convened Sobor primireniia ("the Assembly of Reconciliation") in 1549, following the disturbances in Moscow in 1547. Since, apart from the clergy, the Sobor primireniia included the Boyar Duma ("the Council of Lords"), voevodas ("military governors"), and boyars' sons, this assembly has usually been considered to be the first zemskii sobor by the proponents of the concept. ${ }^{12}$ The exclusively ecclesiastical sobors, however, also continued, and in 1551 Ivan IV convened the Stoglavyi sobor ("the Assembly of a Hundred Chapters") for regulating religious life. In his supposed address to this sobor, the Tsar stressed that he was not only interested in the organization of the land (ustroenie zemskoe) but also in the matters of the Church. ${ }^{13}$

Other major nonexclusively ecclesiastical assemblies were held on the continuation of the war with Poland-Lithuania in 1566, on the "election" of Boris Fedorovich Godunov and Mikhail Fedorovich Romanov Tsars in 1598 and 1613, respectively, on the adoption of the legal Assembly Code (Sobornoe ulozhenie) in 1648-1649, and on the allegiance of the Cossack Hetmanate to the Tsar in 1653. The available sources demonstrated that the members of the assemblies 
were identified through a number of different categories. The 1566 assembly, for instance, included chancellery (prikaz) bureaucrats, gentry (dvoriane), and merchants, in addition to the clergy and the Boyar Duma. The 1613 assembly, called the Zemskii sovet ("the Council of the Land") in some of the sources, included townsmen, Cossacks, and peasants in addition to the groups mentioned in relation to the 1566 assembly. There are sources on further assemblies on different matters. Most of them were called sobor $(1619,1621,1634,1642,1651)$, but there was also another sovet (1616). The membership was not always discussed in detail, with the "people of different rank [chin]" mentioned in the documents. The clergy, which participated in the larger assemblies, was referred to as the Osviashchennyi sobor ("the Holy Assembly"). ${ }^{14}$

The phenomenon of these assemblies was addressed by Russian intellectuals in the nineteenth century, with the development of modern history writing and the emergence of romantic nationalism. Nikolai Mikhailovich Karamzin, one of the first modern historians in Russia, used the terms velikaia duma zemskaia ("the great council of the land"), velikii sobor ("the great assembly"), duma zemskaia ("the council of the land"), and gosudarstvennyi sobor ("the state assembly") when discussing such assemblies. ${ }^{15}$ Karamzin was the first to generalize the duma zemskaia as a larger assembly convened for discussing important state matters. ${ }^{16}$ The term zemskii sobor was used by the Slavophile ${ }^{17}$ author Aleksei Stepanovich Khomiakov in a theater piece in $1833 .{ }^{18}$ Starting with the polemics between Konstantin Sergeevich Aksakov, another Slavophile, and Sergei Mikhailovich Solov'ev on the origins of the zemskii sobors in the $1850 \mathrm{~s}$, the term became frequently used in the historiographic debates. ${ }^{19}$

K. S. Aksakov, Solov'ev, Afansii Prokof'evich Shchapov, Boris Nikolaevich Chicherin, Ivan Dmitrievich Beliaev, Nikolai Ivanovich Kostomarov, Vasilii Ivanovich Sergeevich, Nikolai Pavlovich Zagoskin, Ivan Ivanovich Ditiatin, Sergei Fedorovich Platonov, Valerii Nikolaevich Latkin, and other authors who wrote about zemskii sobors in the $1850 \mathrm{~s}-1880$ s interlaced historical observations, based on scarce sources available then, with their political views and made program statements. Some of their works, based on the premise that the zemskii sobor was a coherent institution, are discussed in the following sections. ${ }^{20}$ Among the findings which proved influential for the twentieth-century debates were Solov'ev's differentiated approach to the sobors and Platonov's interpretation of the sobors as a medium of communication between the government and the localities in the process of administrative centralization of the Russian state. ${ }^{21}$

Vasilii Osipovich Kliuchevskii's study, published in the early 1890s, proved especially influential. Kliuchevskii's main conclusions were based on the study of the sobors of the sixteenth century. He argued that the participation in the sobors was based exclusively on the service position of a participant, who did not represent a particular social group but was summoned by the government to provide information. Kliuchevskii located the origin of the zemskii sobors in the administration of localities. According to Kliuchevskii, the zemskii sobors were always consultative and connected the Tsar to multiple government agents. Kliuchevskii 
noted that in the seventeenth century, the sobors became truly representative but did not go into much detail on the matter. ${ }^{22}$

Later authors in the Russian Empire continued the research of individual sobors and uncovered new sources. A major reinterpretation came with the development of the Marxist historiography in the late imperial and Soviet periods. Mikhail Nikolaevich Pokrovskii integrated the zemskii sobor into his concept of feudalism in Russia. Noting its primitivity in class representation and unclear competence, Pokrovskii defined the zemskii sobor as an extraordinary body of "vassals," with whom the Russian "suzerain" consulted and through which he acted..$^{23}$ In an article accompanying the first Soviet history textbook, authored by him, Pokrovskii defined the zemskii sobors as the assemblies of representatives of landowners and bourgeoisie, using the terms which were common for Soviet political discourse. ${ }^{24}$ Konstantin Mikhailovich Takhtarev, a sociologist and a social democratic activist, defined the "Zemskii sobor" of 1613 as an assembly of estate representatives but stressed its role in ensuring national unity and saving the Russian state in his study of the state from a world history perspective, which he wrote in 1917 and devoted to the "participants of class struggle." Takhtarev included many allusions to the Revolution of 1917, defining, for instance, the zemskii sobor as a "genuine constituent assembly" or stressing the central role which "the union of towns and zemstvos [local self-government bodies]" allegedly played in saving the state. Takhtarev also understood the election of the first Romanov Tsar as limiting autocracy by "popular representation" (narodnoe predstavitel'stvo). ${ }^{25} \mathrm{At}$ the same time, Takhtarev considered the institution's capacity to ensure peace in the society limited, suggesting that the interests of the estates in the second half of the seventeenth century could not be reconciled. ${ }^{26}$

Nikolai Ivanovich Cheliapov, an early Soviet legal scholar, defined the zemskii sobor as a consultative medieval estate assembly and a representative body, similar to the French Estates General. ${ }^{27}$ Serafim Vladimirovich Iushkov and some other early Soviet scholars positioned the zemskii sobor, as a body of estate representation, in the system of estate monarchy, itself part of the feudal period of the Russian history. This was not, however, a predominant view in the 1930s and the 1940s. The Small Soviet Encyclopedia described the zemskii sobors as "partially" similar to other estate assemblies, like the French Estates General. The Great Soviet Encyclopedia, in which Konstantin Vasil'evich Sivkov oversaw the articles on history, mentioned autocracy as a more important factor compared to estate representation, on one instance. On another instance, it called the zemskii sobor a body of central administration in the government's policy of centralization, directed against boyar opposition. On a third instance, the zemskii sobor was called a permanent body in the $1610 \mathrm{~s}^{28}$

Aleksandr Aleksandrovich Zimin, Lev Vladimirovich Cherepnin, and other Soviet historians of later generations interpreted the zemskii sobor as a protoparliament or an "estate representative" body, albeit a consultative one. Ruslan Grigor'evich Skrynnikov noted the broader representation already under Ivan IV, citing the presence of gentry, bureaucracy, and merchants at the 1566 sobor. He also argued that after Ivan IV's death, the zemskii sobors acquired the functions of 
a constituent body, which was at least nominally responsible for the elections of a new Tsar. Fedor I was "elected" by a presumed sobor in 1584, despite being heir apparent to Ivan IV. According to Skrynnikov, the 1584 sobor could be seen as a way to legitimize a new boyar government, given the mental illness of Fedor I. After Fedor I's death, Boris Fedorovich Godunov, a boyar, was "elected" in 1598 by a sobor, or, as Skrynnikov argued, sanctioned post factum by one in 1599 . Skrynnikov noted that there were multiple candidates for the throne, with Fedor Nikitich Romanov, the future Tsar's Mikhail Fedorovich Romanov's father, being Godunov's main competitor for the throne, but the formal "election" itself was not contested, and the power struggle took place in a noninstitutional context. Soviet historians also studied other institutions, such as the Boyar Duma, a smaller government council, a version of which existed as the Zemskaia duma in the second half of the sixteenth century. The zemskaia duma was hence not synonymous to the zemskii sobor, as the nineteenth-century authors implied. ${ }^{29}$

Peter B. Brown disagreed with the Soviet interpretation of the sobors, in particular with that of Cherepnin, pointing to the difference in the genesis and responsibility of each individual sobor, as well as their irregularity. Brown also mentioned the lack of evidence on their memberships and procedures, the diverse memberships of those sobors for which evidence was available, and the fact that the members of the sobors were predominantly appointed and not elected by their social peers. According to Brown, there were no constituencies for electing the sobor delegates, and all but three assemblies (1598, 1613, and 1648-49) seemed to be fully appointed. Peasants were present only at the 1613 assembly, which means that the absolute majority of the male population did not have any theoretical representative rights. Furthermore, Brown argued that there were no social estates in early modern Russia. He concluded that the zemskii sobors were different from the contemporaneous parliamentary bodies in Europe and were not quasi-legislative organs of contentious nobles and urban groups in the fiscal opposition to princes. As such, Brown defined them as irregular "government-summoned consultative assemblies" and "consensus forums" (or "sounding boards") which were used for surveying "public" mood on particular issues. For him, the disappearance of the sobors after the 1650s was hence a result of the bureaucracy becoming superior in information acquisition through the urban voevodas. ${ }^{30}$

Although the debates on sobors have continued, with some historians still comparing them to the assemblies of the estates of the realm in other European polities ${ }^{31}$ and others viewing them as similar to the assemblies (kurultais) in Tatar polities, which together with the Grand Duchy of Muscovy succeeded the Golden Horde, ${ }^{32}$ there has been a growing consensus in English-language studies of early modern Russia, with most scholars agreeing with Brown's interpretation. Marshall Poe called the zemskii sobors "occasional royal councils," which did not limit the authority of the monarch. ${ }^{33}$ Sergei Bogatyrev noted that even the members of the 1566 sobor, one of the more representative ones, saw themselves primarily as the servitors of the Tsar rather than representatives of constituencies..$^{34}$ Endre Sashalmi noted that if the assemblies could influence the government policy, this was only through the expression of "humble requests" which might or might not have been taken into 
account. ${ }^{35}$ Brian Davies reaffirmed that the recognition of the local administrators' capacity to gather information was the main reason for the sobors' disappearance. ${ }^{36}$

Chester Dunning noted the different roles played by the assemblies during the Time of Troubles. He argued that False Dmitrii managed to remain on the throne without convening a zemskii sobor, but listed the lack of an election as a factor undermining Tsar Vasilii Ivanovich Shuiskii. He also discussed the 1611 Sovet vsei zemli ("the Council of the Whole Land"), a sobor-like institution, which resolved numerous minor conflicts between the diverse groups fighting against the Polish-Lithuanian forces. Dunning argued that during Mikhail Fedorovich Romanov's early reign, the sobors helped the Tsar acquire local information and restore state administration, including the flow of taxes, but still foregrounded their bureaucratic functions, which strengthened autocracy, and also called them "sounding boards" with strong links to towns as the main revenue sources. According to Dunning, the members of the sobors acted as advisors loyal to the autocrat rather than any emerging "citizens." 37 The research on later periods of Russian history stressed that the formation of social estates in Russia was a product of a top-down policy in the later decades of the eighteenth century, ${ }^{38}$ confirming that there could be no "estate-representative monarchy" before that. Catherine II made no references to sobors in her Instruction to the Legislative Commission of 1767, which she based on the works of the European Enlightenment authors. ${ }^{39}$

The constituent functions of individual assemblies also remained questioned. Discussing the 1613 assembly, Valerie Kivelson argued that the act of "electing" the Romanov Tsar was a confirmation of God's choice by the Orthodox community. She concluded that popular will remained secondary to God's will. ${ }^{40}$ In this respect, Kivelson rejected the electoral functions of the assemblies - the main feature which, according to Donald Ostrowski, made them similar to the kurultais. ${ }^{41}$ Dunning, however, noted that the 1613 election was contested, though the contestation once again happened behind the scenes of the assembly. ${ }^{42}$

There are certainly still voices supporting the interpretation of the zemskii sobor as a coherent institution. Mikhail Markovich Krom continued to claim that the sobors of the seventeenth century were comparable to European representative institutions and were part of the bottom-up construction of a modern state. Krom argued that the sobors acquired legislative competence, with a sobor promulgating a legal code in 1649 , and that by the middle of the seventeenth century, the sobors had normalized representation for gentry and townsmen. ${ }^{43}$ Richard Hellie considered the zemskii sobors proto-parliaments, focusing on the sobor of 1648-1649, and claimed that their very development into such representative assemblies led to their non-convocation since the $1650 \mathrm{~s}^{44}$ The vast majority of contemporary historians of early modern Russia, however, do not see the zemskii sobor as a proto-parliament or even as a coherent institution.

\section{Autocratic mythology}

The autocratic mythology of the 1613 assembly (Zemskii sovet) developed during the early years of the Romanov dynasty. The Romanov Tsars returned to the 1613 
"election" in the nineteenth and early twentieth centuries. The mythologization of the zemskii sobor as a monarchical institution, in which the Tsar was primary to the people, was reinforced by the Slavophiles in the 1830s-1850s and became especially popular among the monarchist nationalists in the early twentieth century, during the crisis of the Russian Empire. The autocratic mythology was reinvigorated during the Russian Civil War and culminated in the attempted Romanov restoration at the Priamur Zemskii Sobor in Vladivostok in 1922.

The supporters of the Romanovs, the family of Anastasiia Romanovna Zakhar'ina-Iur'eva, Ivan IV's first wife and Fedor I's mother, attempted to sway the anticipated 1613 assembly in their favor. Avraamii Palitsyn, a religious and political figure, wrote during the preparations to the assembly that the Time of Troubles was the divine retribution for the sins of the Russians. According to Palitsyn, the Russian people could not comprehend God's will and committed a number of errors, bringing the unworthy, Boris Fedorovich Godunov, False Dmitry, and Vasilii Ivanovich Shuiskii, to the Russian throne. Palitsyn argued that the person who had the qualities of a perfect Orthodox Tsar - piety, reason in governance, and military valor - was Fedor Nikitich Romanov, and God wanted to see him on the throne. After the Russian people elected Boris Fedorovich Godunov, they were punished. Palitsyn also tried to convey the similarity between Fedor I, the last Tsar of the Rurik dynasty, and Mikhail Fedorovich Romanov, Fedor Romanov's son, in their piety, and suggested that if the pious relative of the late Tsar Fedor I was enthroned, God would grant Russia peace. This narrative had some effect but did not guarantee the victory of Mikhail Fedorovich Romanov, and the Romanovs' supporters opted for popularizing the earlier legend of Tsar Fedor I bequeathing the authority to Fedor Nikitich Romanov. ${ }^{45}$

The notion of following God's will at the 1613 assembly reflected in its main document, Utverzhdennaia gramota ("the Approved Charter"). According to the document, during the 1613 Zemskii sovet (or simply sobor), which convened for "electing" a Tsar, God sent "His Holy Spirit to the hearts of all Orthodox Christians of the whole great Russian Tsardom." Electing Mikhail Fedorovich Romanov the new Tsar, the people followed God's will. The assembly was accompanied by a general prayer which was supposed to reveal it. The document also mentioned rational arguments in support of the decision, noting the relation of Fedor Nikitich Romanov and the late Tsar Fedor I and even the alleged opinion of the Swedish King, whose forces occupied parts of the Russian state, that a Russian had to sit on the Russian throne. God's will was nevertheless presented as the main source of the unanimous "election" of Mikhail Fedorovich, who was called "elected by God" in the text. ${ }^{46}$ The primacy of God's will and mercy in the "election" of the Tsar was reaffirmed in later chronicles ${ }^{47}$ and Palitsyn's Skazanie ("Tale"), which stressed that God heard the collective prayer and granted Russia the new Tsar. ${ }^{48}$ The manuscript Kniga ob izbranii na tsarstvo Velikogo Gosudaria, Tsaria $i$ Velikogo Kniazia Mikhaila Fedorovicha ("The Book on the Election of Mikhail Fedorovich to the Throne of the Great Master, Tsar and Grand Duke"), which was written under the supervision of the boyar Artamon Sergeevich Matveev, who is occasionally called "one of the first Westernizers," ${ }^{\prime 9}$ in the 1670s, mentioned 
deliberation about candidates and presented the "election" as a multistage process, even though it also foregrounded God's will. ${ }^{50}$

The autocratic mythology was revived in the nineteenth century. Karamzin's approach to Russia's early modern assemblies as an institution included the participation of the people and hence contributed to democratic ideas, but the author himself foregrounded autocracy. He was critical of the limited autocracy during Tsar Fedor I's rule with the Boyar Duma. According to Karamzin, after the election of Boris Fedorovich Godunov Tsar in 1598, the Patriarch proclaimed to the sobor that "the voice of the people" was "the voice of God," and hence the new Tsar was elected according to God's will. ${ }^{51}$ Discussing the 1611 Sovet vsei zemsli (which he called duma zemskaia), Karamzin deemed the reestablished Russian government a "shadow" of one, since without an autocrat a government in an autocracy was "soulless." 52

The Slavophiles, who idealized ancient Russia and rejected Russia's alleged inferiority to the West, became especially influential in creating a coherent autocratic mythology of the zemskii sobors. Although it was A. S. Khomiakov who introduced the term to the nineteenth-century discussions, he did not use it when considering the nature of the supposed institution in 1839. According to A. S. Khomiakov, the "friendship of the government [the Tsar] and the people" manifested itself in the "old custom" of "assembling deputies of all estates for the discussion of the most important state issues," which survived under Tsar Aleksei Mikhailovich. ${ }^{53}$ The Slavophile K. S. Aksakov combined Khomiakov's term and understanding of the alleged institution in his early-1850s manuscript and located the origins of the zemskii sobor in the Slavic traditional community (obshchina), which was based on giving up self-interest in favor of absolute consensus (edinoglasie) or love - the central idea of the romantic nationalism of the Slavophiles. He argued that the assemblies, such as veche ("assembly" or "council"), sobor, and duma, were the embodiment of the community's moral activity and could not conclude before reaching a consensus. The first zemskii sobor, according to K. S. Aksakov, embodied the unification of the Russian land in one state under Tsar Ivan IV. After the unification, the land (zemlia) acquired the right to opinion and speech, while the state enjoyed the unlimited right to action and legislation. ${ }^{54}$ The land was hence the new manifestation of the community. According to the Slavophiles, Russia's increasing closeness to the West corrupted its popular order, resulting in the crisis of the institutions of the land and the emergence of the German bureaucracy around the Tsar, but a revival was deemed possible. ${ }^{55}$

K. S. Aksakov was also the first one to bring the concept of zemskii sobor into politics by including it into his 1855 memorandum to Alexander II. He stressed the connection between the government and the people in his understanding of the alleged institution. Applauding the "wisdom" of the Tsars, he claimed that they convened the zemskii sobors of those elected from all estates of Russia and offered them different issues for discussion. K. S. Aksakov argued, however, that the government was aware that it did not concede any rights to the zemskii sobors, while the people knew that the assemblies did not acquire any, asserting that the relations between the assemblies and the government were "friendly" 
and "full of trust." K. S. Aksakov maintained that such assemblies were radically different from parliaments but nevertheless stressed their role in surveying public opinion. This conformed to his main suggestion of gradually introducing full freedom of speech and press, when it would become clear that it was "inseparably connected to unrestrained monarchy." Although K. S. Aksakov suggested convening a zemskii sobor when the government desired to ask for the country's opinion, he opposed its immediate convocation. He deemed an immediate zemskii sobor pointless due to the remoteness of the nobles from the "popular foundations" and the fascination of both the nobles and the merchants with the West, which allegedly made it impossible to gather "the voice of the whole Russian land" at such an assembly. According to K. S. Aksakov, before a zemskii sobor could be convened, the freely expressed public opinion could perform its role. He also proposed convening assemblies of individual estates but emphasized that such assemblies and the future zemskii sobors were to be irregular and that their convocation was not supposed to be the government's obligation. ${ }^{56}$

Although Tsar Alexander II did not implement K. S. Aksakov's suggestions on the freedom of speech and press and the irregular estate assemblies, the government returned to the mythology of the "election" of the first Romanovs at the 1613 Zemskii sovet. The introduction to Kniga ob izbranii na tsarstvo Velikogo Gosudaria, Tsaria i Velikogo Kniazia Mikhaila Fedorovicha, which was published by an official commission on Royal decree in 1856, maintained that "the whole people" or "the people of the land" (zemskie liudi) decided that it was not possible to be "without a master," ${ }^{, 57}$ reaffirming thereby the autocratic mythology of the assembly.

Some Slavophiles continued to use alternative terms when speaking of the premodern assemblies. Aleksandr Ivanovich Koshelev published a pamphlet in Leipzig in 1862 in which he called for a general zemskaia duma. Although it was supposed to be a consultative body, tasked with informing the Tsar about the needs of the country, Koshelev also expected it to form the cabinet, which connected it to the democratic slogans. He published another pamphlet on the zemskaia duma the same year. ${ }^{58}$ Later Slavophiles popularized K. S. Aksakov's term and understanding of the zemskii sobor. Il'ia Vasil'evich Beliaev reaffirmed the connection of the zemskii sobor to the ancient Slavic veche in his 1866 popular history book. He also noted that after the unification of Russia under one Tsar, Ivan IV, "the first Russian Tsar convened the first veche of the whole Russian land or the zemskii sobor." Citing the Tsar's criticism of the boyar rule, I. V. Beliaev interpreted the assembly as the symbolic start of autocracy, since the Tsar took full authority himself. According to I. V. Beliaev, the assembly was highly emotional. "The Tsar and the people burst into tears. This was the opening of the first zemskii sobor." ${ }^{59}$ In his 1867 speech, the Slavophile I. D. Beliaev also argued that the zemskii sobor finished the unification of Russia and strengthened autocracy but noted that it was not similar to the previous veches, since it was convened by the will of the Tsar and included representatives and not the whole political communities of towns, which were present at the veches. ${ }^{60}$ 
In 1874, Konstantin Dmitrievich Kavelin, a former Westernizer and a former Slavophile, provided a different explanation for the possibility of representative institutions in autocracies. He generalized veches and zemskii sobors as a form of elected state representation, comparing them to the Estates General and assemblies in Germany, but argued that they predated absolutism. He concluded that the supposed limitation of state power (monarchy) through representation was hence invented in response to European history since the late eighteenth century (implying the French Revolution), but this did not mean that representation could not exist in other contexts. ${ }^{61}$ In his unpublished 1880 article, Kavelin translated his historical observations into the idea of a general zemskii sobor under the autocratic Tsar, which was similar to the Slavophile designs but was based on comparative argumentation rather than on Russia's exclusivity. ${ }^{62}$

The zemskii sobor was discussed in the top tier of Russia's ruling elite as well. After the assassination of Alexander II, his brother Konstantin Nikolaevich Romanov was allegedly convinced that only the convocation of a zemskii sobor could save Russia. ${ }^{63}$ The Slavophiles nevertheless did not find support for a possible political reform among the new conservative ruling circles. Minister of Internal Affairs Nikolai Pavlovich Ignat'ev, who supported Slavophile ideas, proposed to the new Tsar Alexander III to convene a consultative zemskii sobor of some 3,000 people simultaneously with his coronation in 1882. Ivan Sergeevich Aksakov, K. S. Aksakov's brother, and Pavel Dmitrievich Golokhvastov, who were the main authors of Ignat'ev's proposal, reinforced the autocratic mythology in their publications, but Alexander III rejected it and made Ignat'ev resign. ${ }^{64}$

The zemskii sobor as a monarchist slogan, however, survived. In 1889, Aleksandr Alekseevich Kireev, a writer and a general, summed up the Slavophile suggestions of reintroducing the consultative zemskii sobors - the councils of the Tsar with the land - not for limiting the power of the ruler but for helping him with local information. The Tsar, according to Kireev, represented the single will, while the sovet zemli ("the council of the land") represented the many minds. He argued that the Russian people needed a strong yet understanding government for the people's self-improvement but rejected politicking. Kireev also stressed the unity of the state and the Orthodox Church as the ultimate ideal of the society. ${ }^{65}$

The idea of a revived zemskii sobor loomed large in response to the demands of a "popular representation," an expression used for a parliament, by liberal and moderate socialist intellectuals. The socialist turned conservative Lev Aleksandrovich Tikhomirov argued in 1902 that the direct communication between the supreme authority and the people was possible only in an organized nation, while in a disorganized one, the bureaucracy was a "mediastinum" which isolated the authority from the people. A parliament, according to Tikhomirov, could not reestablish the communication, since the deputies only expressed the will of the "politicking estate," and in fact even increased the separation between the state and the nation. He asserted that only the creative and conservative (okhranitel'nyi) stratum could enable the government's [the Tsar's] communication with the "spirit of the people." According to Tikhomirov, such communication could take place in a zemskii sobor but could also occur directly through individuals. ${ }^{66}$ 


\section{Ivan Sablin and Kuzma Kukushkin}

The Slavophile interpretation of the premodern and pre-Petrine Russian state in general and the zemskii sobor in particular contributed greatly to the debates of a political reform shortly before and during the Revolution of 1905-1907. ${ }^{67}$ In the fall of 1904, Petr Sergeevich Porokhovshchikov, a jurist and a right-wing author, proposed a "revival" of the zemskii sobor. In January 1905, a meeting of Saint Petersburg editors composed an address to Minister of Internal Affairs Petr Dmitrievich Sviatopolk-Mirskii, suggesting to convene a zemskii sobor of representatives from all estates and classes with "the unlimited freedom of opinions." The same month the idea was reaffirmed in a newspaper article by the publisher Aleksei Sergeevich Suvorin. Apart from establishing the communication between the Tsar and the "whole Russian land" and ensuring a strong government, Suvorin expected the zemskii sobor to raise the international prestige of Russian monarchy, especially among the Slavic peoples. In another article, published in February, Suvorin specified that the sobor was to consist of some thousand deputies, while the elections were to be almost universal, including women and the ethnic non-Russians who knew the Russian language. The idea of the zemskii sobor was supported by several other Slavophile and right-wing authors at the time. Some monarchists seemed to agree on an irregular sobor, which would meet on the Tsar's orders and be primarily used for channeling the needs of the people to the Tsar. Its decisions would not be binding for the government. ${ }^{68}$ Nikolai Nikolaevich Mazurenko's pamphlet, published in 1905, backed the program with historical arguments. Mazurenko claimed that Russian monarchs frequently convened sobors for listening to the opinion of the people and interpreted Catherine II's Legislative Commission of estate representatives as a zemskii sobor. ${ }^{69}$

Many right-wing intellectuals and activists agreed to a one-time sobor if the monarch deemed it necessary, but some of the monarchists, who opposed any changes which could threaten the autocracy, saw the very idea as a compromise and rejected it. Vladimir Andreevich Gringmut, a far-right author and a politician, for instance accused the Slavophiles of a "mystical or aesthetical" policy. ${ }^{70}$ Andrei Sergeevich Viazigin, a historian and later a member of the Third State Duma, also dismissed the idea completely. In 1905, he argued that the zemskii sobor existed when the "tops and bottoms" of the society had the same worldview. According to Viazigin, in the situation when the Russians were fragmented into numerous social strata, including classes, its revival was not possible. He also argued that the function of gathering local information could be easily performed by press, telegraph, and telephone and did not require a zemskii sobor. ${ }^{71}$

Officials also discussed a possible zemskii sobor since January 1905 in the context of the revolution and the disastrous Russo-Japanese War (1904-1905). In February 1905, the Council of Ministers under Nicholas II's presidency considered a possible consultative and irregular zemskii sobor, elected from the estates, but there was no unity in the cabinet on the matter. In March 1905, Minister of Agriculture and State Property Aleksei Sergeevich Ermolov suggested in a letter, which was passed to Nicholas II, to establish a people's zemskaia duma, freely elected from all classes and estates, for direct communication between the Tsar and the people on the most pressing issues. Anatolii Ivanovich Kulomzin, a 
member of the State Council, proposed a bureaucratic sobor of the existing government bodies and four representatives from each province (from the clergy, the landowners, the merchants, and the peasants, respectively). ${ }^{72}$

The far right continued to oppose the idea of a sobor, but the zemskii sobor in Kireev's interpretation became a popular idea among the broader right. Kireev criticized "bureaucratic autocracy" and deemed the zemskii sobor an alternative to revolution. His plan was to transform autocracy from bureaucratic into "consultative" through a sobor. In March 1905, the idea of combining autocracy with popular representation, put forward by Nikolai Alekseevich Khomiakov, A. S. Khomiakov's son, was backed by a meeting of several leaders of provincial nobility, but there were also provincial noble assemblies which rejected it. Interestingly, Fedor Dmitrievich Samarin, the son of another early Slavophile Dmitrii Fedorovich Samarin, rejected the idea of a sobor, claiming that it would inevitably turn into a parliament and stimulate the revolution. The same month, a group of right-wing politicians under Aleksei Aleksandrovich Bobrinskii united into a party, the Patriotic Union (Otechestvennyi soiuz), and discussed their own project of a zemskii sobor. Vladimir Iosifovich Gurko drafted the electoral regulations, according to which the sobor was to include 612 deputies, elected from different groups of the population based on property or land qualifications, expecting that the peasants and the landowners would form the largest groups. The sobor was to convene for a short period to resolve the most urgent matters of state life, but it was also to form a standing body, the zemskaia duma of 128 members, which would participate in drafting legislation. The Patriotic Union debated on how not to prevent the intelligentsia from being elected to the sobor and resolved to raise the qualifications. ${ }^{73}$

A governmental commission, which was created on the initiative of Minister of Internal Affairs Aleksandr Grigor'evich Bulygin and began its meetings in March 1905, nevertheless resolved that a zemskii sobor was not suitable and suggested a permanent assembly of 400-500 people, the State Duma. In May 1905, however, Nicholas II still expressed interest in a zemskii sobor. The idea gained momentum after the defeat in the Battle of Tsushima (May 14-15, 1905), with a possible sobor assembling to discuss the continuation of the war with Japan. The projects prepared at this time suggested the use of parishes (including the territorial divisions of non-Orthodox faiths) as the basic electoral units. The sobor, from 200 to 1,000 deputies, according to different projects, was expected to be convened as soon as possible, for instance, in August 1905. On May 23, however, Nicholas II presented Bulygin commission's project of a bicameral consultative body, consisting of the State Duma and the State Council, to the Council of Ministers. At the special meeting on May 24, Bulygin cautioned that a possible zemskii sobor would lead to a constitution and turn into a constituent assembly, and the project of his commission prevailed. In June 1905, Nicholas II, however, still spoke of reestablishing the old connection between the Tsar and All Rus', repeating the Slavophiles' slogans, but approved the project of the consultative State Duma later that summer. On October 17, 1905, the Duma was made legislative. ${ }^{74}$ 


\section{Ivan Sablin and Kuzma Kukushkin}

Right-wing politicians nevertheless did not abandon the idea of a zemskii sobor, presenting it as an alternative to the legislative State Duma. In December 1905, the far-right Union of the Russian People (Soiuz russkikh liudei), headed by Aleksandr Grigor'evich Shcherbatov, appealed to the Tsar, promising to defend autocracy and asking him to convene a "great zemskii sobor" of the Russian people, based on faith and descendance, the people who had "enthroned" Nicolas II's ancestor, in Moscow. The sobor was to be formed from the existing estate bodies. ${ }^{75}$ In 1906, ahead of the convocation of the First State Duma, a proclamation of the Union of the Russian People defended autocracy but argued that the unity of the Tsar and the people was to be manifested through the consultation with the State Duma and the zemskii sobors. The latter were to be convened for discussing fundamental laws, "extraordinary" events of state life, and the general directions of domestic policy. ${ }^{76}$ In its 1906 program, the Union of the Russian People specified that the "original Russian Orthodox land-state community [zemsko-gosudarstvennaia sobornost']" was to be manifested in the zemskii sobor or the State Duma of Orthodox Russians, based on the estate principle and elected from the Church or administrative units. All non-Orthodox peoples were to be included into the sobor or the Duma as petitioners. ${ }^{77}$

Sergei Fedorovich Sharapov, a founding member of the Union of the Russian People, was one of the main advocates of a zemskii sobor in the Slavophile understanding and included it into his vision of future Russia. In his political program, he specified that the future zemskii sobor was to be a consultative body and could not have constituent power. ${ }^{78}$ In his 1907 speech, Sharapov denounced the convocation of the Third State Duma after the alleged complete failure of parliamentarism, which for him manifested in the first two Dumas (1906 and 1907), and proposed to return "to the genuinely Russian foundations and the covenants of history" and to convene "a zemskii sobor" in Moscow instead. ${ }^{79}$

Tikhomirov was among the minority of right-wing intellectuals, arguing that the introduction of a "popular representation" was the only positive outcome of the 1905-1906 events. He nevertheless advocated a monarchist reform of the legislature. Tikhomirov proposed to create a Legislative Council (Zakonodatel'nyi sovet) which would discuss and draft laws and pass them to the Tsar. The body was to be formed by appointment and through nomination from "organized societal institutions," such as "zemstvos, municipal, social estate, and professional organizations." Tikhomirov also suggested forming an elected People's Duma (Narodnaia duma) which would deal with all matters on which the Tsar wanted “to consult with the people." The People's Duma was supposed to convene every three years for three to four months. According to his project, in extraordinary cases, the Tsar could also convene a zemskii sobor, which would consist of the Legislative Council, ministries, the supreme Church authority, the supreme legislative authority, the supreme command, the People's Duma, and further representatives of social estates, as well as the individuals who performed meritorious service to the Fatherland..$^{80}$

There is no evidence that the government seriously considered returning to the idea of a zemskii sobor despite its conflict with the oppositional State Duma, but 
in June 1907, the month when the Second Duma was dissolved and the electoral law was replaced by a more restrictive one, marking the end of the Revolution of 1905-1907, Prime Minister Petr Arkad'evich Stolypin mentioned a zemskii sobor (instead of the State Duma) in his notes on the planned dissolution of the parliament. ${ }^{81}$ In 1907-1917, the discussions of the zemskii sobor shifted to the background but continued. The Archangel Michael Russian People's Union (Russkii narodnyi soiuz imeni Mikhaila Arkhangela), a far-right organization, campaigned for making the State Duma consultative in 1912. The zemskii sobors were to be a historical example for such a body of communication between the Tsar and the people, which did not limit autocracy. The organization also reaffirmed God's will in autocratic decision-making, suggesting that the Tsar's decisions were based on "God's truth." 82 Shcherbatov returned to the idea of convening a zemskii sobor in extraordinary circumstances in a 1912 publication. He suggested that only "officials" of different social estates could be nominated to the sobors, while the ultimate selection was to be done by lot. ${ }^{83}$

The publications, accompanying the celebration of the 300th anniversary of the Romanov dynasty in 1913, foregrounded the monarchist and patriotic meanings of the 1613 events. A popular brochure, for instance, stressed the general popular consensus in the election of the Romanovs. ${ }^{84}$ The historian Dmitrii Vladimirovich Tsvetaev stressed the connections of the zemskii sobors to local communal councils and celebrated both the unification of Russia around Moscow and monarchy. ${ }^{85}$ The popular print by Antonina Khristianovna Vestfalen placed Mikhail Fedorovich and his mother Marfa (Kseniia Ivanovna Shestova) at the center of the composition, while religious and lay figures, most likely representing the 1613 Zemskii sovet, bowed before them (see Figure 4.1).

With the Revolution of 1917, and especially the Civil War of 1918-1922, the political discussions of the zemskii sobor were revived. Some left politicians ironically called the Moscow State Conference (Gosudarstvennoe soveshchanie), which united deputies of the four imperial State Dumas and representatives of self-government bodies, soviets, the Army and the Navy, trade unions, cooperative societies, non-Russian national organizations, and other groups on August 12-15, 1917, a "zemskii sobor," implying its alleged counterrevolutionary character, but the left members of the Provisional Government defended its convocation. ${ }^{86}$ In contrast with the 1905-1907 events, the zemskii sobor as a monarchist slogan was much less popular than the democratic takes on the institution in 1917-1922.

In the monarchist sense, the idea of a zemskii sobor was evoked by anti-Bolshevik politicians in Manchuria and the Russian Far East, with the mythology of the Time of Troubles playing a pivotal role. The monarchist Nikolai Aleksandrovich Andrushkevich, for instance, proposed the idea to the anti-Bolshevik Vladivostok government in 1921 as a way to resolve the crisis in whole Russia. Such an assembly in a modified regional form was convened in Vladivostok on July 23-August 10, 1922, under the name of the Priamur Zemskii Sobor. Although initially it was not clearly aimed at reestablishing monarchy, it marginalized moderate anti-Bolsheviks, foregrounding the ultra-royalists who indeed aspired to find a 


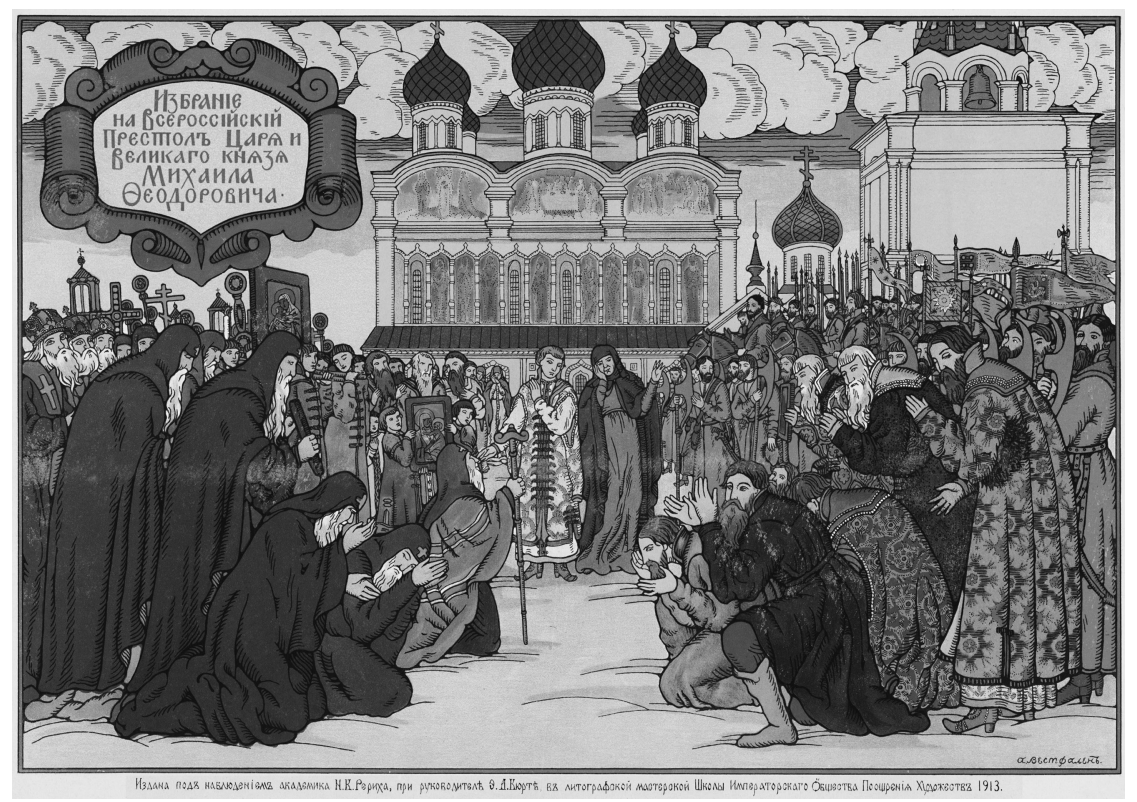

Figure 4.1 A. Kh. Vestfalen. Izbranie na Vserossiiskii Prestol Tsaria i Velikogo Kniazia Mikhaila Fedorovicha [The election of Mikhail Fedorovich to the All-Russian Throne of Tsar and Grand Duke]. Saint Peterburg: Litografskaia masterskaia Imperatorskogo obshchestva pooshchreniia khudozhestv, 1913.

new Romanov Tsar. ${ }^{87}$ The Priamur Zemskii Sobor became the first institution in Russian history to include the words zemskii sobor into its official name.

The Priamur Zemskii Sobor included delegates from the existing anti-Bolshevik authorities, as well as representatives of the clergy, the military, public agencies, nonsocialist organizations, landlords, rural population, trade and industrial class, Orthodox parishes, Old Believer communities, and other organizations. It also included the Main Army Mullah, apparently representing the Tatars and the Bashkirs among the anti-Bolshevik troops. Workers' representatives were also formally included, but Communists and their supporters, as well as other socialists-internationalists, were not allowed to participate in the Priamur Zemskii Sobor. Uniting some 230 delegates, the assembly became a historical reenactment, a new "Resurrection of Muscovy." Its Presidium was located in front of an iconostasis-like screen featuring an icon of Jesus Christ and simpler depictions of archangels and Saint George. Although some of its members opposed reestablishing monarchy, the sobor elected Mikhail Konstantinovich Diterikhs provisional dictator and sent a delegation to the members of House Romanov living abroad for finding a candidate for the throne. Ultimately, no candidate was provided by the Romanovs. Diterikhs, nevertheless, extensively used the mythology of the Time of Troubles in his short-lived regime (toppled in October 1922) and convened a 
consultative zemskaia duma. Furthermore, the planned reconstruction of regional government featured making the parishes basic administrative units. ${ }^{88}$

\section{Democratic mythology}

The democratic mythology of the zemskii sobors emerged in the 1820 s with the fusion of civic ${ }^{89}$ and romantic nationalism in the Decemberist Revolt of 1825 . Since the 1850s, the evaluations of the zemskii sobors vis-à-vis European parliaments accompanied the historiographic and political debates. The ideas of decentralization proved especially important for the development of the democratic mythology. Since the 1860 s, the idea of the zemskii sobor had attracted the attention of oppositional intellectuals who integrated it into their political programs, with the establishment of a zemskii sobor becoming a slogan of some Russian socialists and regionalists. Several historical works developed the vision of the zemskii sobor as a Russian "parliament" or a "proto-parliament," but the term in such interpretation did not enter the mainstream liberal discourse. The democratic interpretations of the zemskii sobor nevertheless predominated during the Russian Civil War of 1918-1922, even though the concept proved marginal compared to the much more popular slogan of the All-Russian Constituent Assembly.

The concept of an early modern representative institution was known to the Russian ruling elites (see Chapter 1 in this volume). The word sobor was sometimes used in the translated news on the European assemblies in the seventeenth century, for instance, when discussing the English Parliament in 1627-1628, but the term sejm (soim) was more frequent. The adjective zemskii was, however, often used in relation to foreign assemblies, dubbed zemskaia soim. The word parliament (parlament) was used in the discussion of English politics already in the 1640 s. ${ }^{90}$

In the eighteenth century, foreign terms predominated, and it was only sovet which was continuously used for the projected and introduced collegial bodies, such as the Supreme Privy Council (Verkhovnyi tainyi sovet), which was supposed to limit autocracy in 1730, or the Imperial Council (Imperatorskii sovet), which was another proposed body for limiting autocracy in $1762 .{ }^{91}$ The participants of the 1730 discussions did not reference the sobors at all and drew inspiration from the Sejm of Poland-Lithuania. Vasilii Nikitich Tatishchev, who authored one of the first modern takes on Russian history in the first half of the eighteenth century, also did not discuss the sobors as an institution when investigating Russia's political development. ${ }^{92}$

The nationalization (or vernacularization) of the discourse on modern representative institutions happened in Russia before the terms entered historical mainstream. The statesman Mikhail Mikhailovich Speranskii became the first to introduce the word duma into the modern political discourse in his project of the legislative State Duma and the dumas at different levels of self-government in 1809. Furthermore, he did so with a direct appeal to the supposed attempts to limit autocracy under Tsar Alexei Mikhailovich through the council which included "part of the people." "93 Karamzin contributed to the rejection of the 
State Duma by Alexander I by accusing Speranskii of the attempts to reduce the status of the monarch to that of the executive branch..$^{94}$ The 1820 constitutional project, submitted by Nikolai Nikolaevich Novosil'tsev, the Russian official in charge of the Kingdom (Tsardom) of Poland at the time, used the Polish word sejm and the State Duma interchangeably for the projected parliament. Its lower Ambassadorial Chamber was to include zemskie posly "ambassadors of the land," just like in Poland-Lithuania. Even though the term was also borrowed from the Constitution, which Alexander I granted to the Kingdom of Poland in 1815, just like sejm, the word zemskie was a Russian addition. The project was also rejected by Alexander I. ${ }^{95}$

Karamzin contributed to both autocratic and democratic takes on the historical assemblies. Karamzin wrote that it was the government around Tsar Fedor I which convened the velikaia duma zemskaia of the clergy, gentry, and all honorable people for settling some general matters of the state, generalizing that such dumas were convened for important state decisions. ${ }^{96}$ Karamzin also implied the right of the duma zemskaia to depose a monarch, claiming that Vasilii Ivanovich Shuiskii told his opponents that only this institution of "great boyars and state ranks" could resolve the fate of the country and his own and depose him. ${ }^{97}$ Furthermore, Karamzin mentioned that the Russians considered limiting autocracy by delegating the authority in justice and taxation to the boyars and "civil legislation" to a zemskaia duma in the talks with the Poles during the Time of Troubles. ${ }^{98}$ As mentioned above, Karamzin also paid attention to the duma zemskaia existing without a Tsar during this period. ${ }^{99}$

Even though Karamzin's detailed discussion of the duma zemskaia was published in 1829, the future participants of the 1825 Decemberist Revolt used the terms duma and sobor in Karamzin's interpretation of such a historical assembly in their political projects already in the first half of the 1820s. Ivan Dmitrievich Iakushkin drafted an address to Alexander I, suggesting to convene a zemskaia duma for overcoming Russia's troubles, just like the Tsar's ancestors did. According to Kondratii Fedorovich Ryleev's testimony, if the Decemberist Revolt succeeded, the Great sobor of popular representatives would make decisions on the future of the dynasty, the system of government, and Poland's independence. Nikita Mikhailovich Murav'ev, whose acquaintance with Karamzin's studies was documented, included the archaic terms into his draft Constitution. In Murav'ev's federalist project, the Supreme Duma (Verkhovnaia duma) was the lower chamber of the federal parliament, called the People's Assembly (Narodnoe veche). Each state of the federation was also to have a bicameral parliament, with a derzhavnaia duma ("duma of a state") being one of the chambers. Murav'ev reserved the right to amend the Constitution and elect a new Tsar for the "People's" (Narodnyi) and State sobors. The constitutional project of Pavel Ivanovich Pestel' also included a parliament, called Narodnoe veche, while the Derzhavnaia duma was the proposed name for the cabinet. Pestel' also spoke of a "controlling" (bliustitel'naia) branch of power, which was to be represented by the Supreme sobor (Verkhnovnyi sobor). Furthermore, his project featured the convocation of a constituent sobor (called "people's" or "representative"). According to Pestel', the latter could not, 
however, be convened immediately due to the lack of foundations for representative rule in Russia and therefore a provisional government was needed after the revolt. ${ }^{100}$ After the Decemberist Revolt was suppressed, the suggestions to revive a supposed historical Russian assembly as a modern democratic institution subsided for several decades.

Since the 1840s, the Westernizers, the opponents of Russia's exclusivity, polemicized with the Slavophiles on the nature of historical institutions. In 1847, Vissarion Grigor'evich Belinskii rejected the idea that consensus at the veche and, in the case of Novgorod, between the veche and the prince was unique for the Slavic community. He argued that it embodied decision-making by majority and was hence the same as in constitutional states, including constitutional monarchies. He then argued that it was the Germanic peoples who developed the communal principle by making law its foundation. ${ }^{101}$ The Westernizers also criticized the Slavophile moral idealism. Konstantin Nikolaevich Bestuzhev-Riumin, for instance, argued in 1862 that absolute consensus (edinoglasie) was incompatible with the civil society, which was based on the struggle of opinions and parties. He denounced the Slavophile interpretation of the zemskii sobor as the "veche of the whole Russian land," arguing that the early modern sobors were an institutional development rather than a revival of an ancient assembly. ${ }^{102}$

In the early $1860 \mathrm{~s}$, however, historical terms again became popular among the critics of autocracy, stimulating the development of the zemskii sobor's democratic mythology. The ideas of regionalism and decentralization proved especially important for Shchapov's interpretation of the zemskii sobor, which he articulated in late 1860 in his first lecture at the University of Kazan. ${ }^{103}$ Shchapov located the origins of the zemskii sobors in the original "land-regional" (zemsko-oblastnaia) form of the "historical development of the Great Russian people." According to Shchapov, the regions were lands and hence a regional popular assembly was called zemskii sovet. Shchapov argued that the 1613 "Zemskii sobor" (or sovet) embodied the "land-regional" form's principle of zemskoe narodosovetie ("the people-council [system] of the land") and formally limited autocracy. He argued that later sobors functioned on the same principle. According to Shchapov, in the second half of the seventeenth century, this form gave way to the "state-union" one, and the state began to play the leading role. ${ }^{104} \mathrm{~A}$ few months later, in May 1861, Shchapov sent a letter to Alexander II outlining a reform project based on his theory. He proposed "reestablishing" the regional all-estate zemskii sovets and the central zemskii sobors (or sovets), elected by the former, as a continuation of the general revival of the ancient structure, which for Shchapov began with the emancipation of the serfs on February 19, 1861. The central sobors were supposed to discuss state matters, represent provincial interests and needs, report on taxes, and provide information for legislation. ${ }^{105}$

In his letter to the imperial official Pavel Petrovich Viazemskii, written in October 1861, Shchapov outlined his federalist vision of future Russia, consisting of self-organized communities, and based on zemskoe narodosovetie. He reiterated the claim that the Great Moscow zemskii sovet or sobor of 1613 limited autocracy by a written act, which the Tsars Alexei Mikhailovich and Peter 
I violated. Furthermore, Shchapov stressed that the people elected the Tsar but made the wrong choice. Shchapov then suggested that during the celebration of the 1,000th anniversary of Russia's statehood, which was supposed to take place in 1862, the people should gather for a new zemskii sobor, either by themselves or after being summoned by the Tsar, "renounce the emperor and centralization, grant autonomy to Poland, Ukraine, Great Russia, Siberia, and all provinces, and create a federative social democratic constitution, the union, communal-democratic zemskoe narodosovetie." Shchapov asserted that by initiating the bottom-up self-organization of the whole country through assemblies at different levels and ultimately through the "all-Russian great union or federal zemskii sovet, s"ezd ('congress'), sobor" was the way for the Tsar to avoid a revolution. The Tsar, Shchapov argued, would naturally have to renounce autocracy. ${ }^{106}$ In March 1862, he published an article in a Saint Petersburg periodical on the zemskii sobors in the seventeenth century where he again mentioned the role of the 1613 assembly as a popular government and the act which supposedly limited autocracy. ${ }^{107}$

Aleksandr Ivanovich Gertsen and Nikolai Platonovich Ogarev, living in London, and other authors of the émigré opposition articulated the idea of the zemskii sobor as a manifestation of popular sovereignty even more prominently. Shchapovs's letter to Viazemskii was copied and sent to Gertsen by the members of the first Land and Freedom (Zemlia $i$ volia) secret society (1861-1864) in early $1862 .{ }^{108}$ In late 1862 , Gertsen used the terms duma and zemskii sobor as synonyms for a parliament, to which the cabinet should be responsible. His newspaper Kolokol ("The Bell") also published a proclamation of Russian officers in Poland then, which called for convening a zemskii sobor, elected from the whole Russian land, for establishing a union of autonomous regions and a rational system, which was similar to Shchapov's ideas. The same year, Petr Vladimirovich Dolgorukov, another émigré author, suggested establishing constitutional monarchy, with the zemskaia duma (which in his 1860 historical narrative of Russia was a synonym to zemskii sobor) being one of the parliament's chambers. Petr Alekseevich Mart'ianov, a former serf, who also emigrated to London and met Gertsen and Ogarev there, outlined his vision of the future Russian state in a letter to Alexander II and a pamphlet in 1862. In the letter, Mart'ianov proposed the concept of estateless people's monarchy, headed by a zemskii Tsar. In the pamphlet, he defined the people as the zemstvo, which was oppressed by the state. In the new system, proposed by Mart'ianov, the representative government of the people was to be headed by the Great All-Popular zemskaia duma, the manifestation of the union and unity of the whole Slavic world. ${ }^{109}$

The term zemskii sobor predominated among the émigré opposition. In June 1862, Ogarev, who advocated making Russia a federation of autonomous regions since $1861,{ }^{110}$ interpreted the zemskii sobor as a parliament, limiting autocracy, in a draft address to Alexander II, which was approved by Gertsen and Mikhail Aleksandrovich Bakunin but never submitted. In early 1863, Gertsen claimed that the year 1862 was a pause, after the 1861 emancipation of the serfs, and the eve of the convocation of a zemskii sobor. The latter was supposed to limit autocracy through a constitution, which had to be composed by the people and the Tsar by 
February 19, 1863. Gertsen concluded by urging Alexander II to trust his people at the anticipated zemskii sobor. Over the course of 1863, Kolokol published Ogarev's article Constitution and the Zemskii sobor. He defined the zemskii sobor as the congress of deputies, which was supposed to be elected from the whole zemstvo (most likely "the people" in Mart'ianov's understanding) in estateless elections and to organize the Russian land according to the needs of the zemstvo. It was supposed to legalize land use rights, introduce elected administration and court, regulate the relations between regions, and establish a new system of government. The first zemskii sobor was supposed to be provisional and elected from districts. It was to establish the new system of the state, delimiting the borders between regions and granting the legal basis for regional dumas. The second zemskii sobor was supposed to convene, based on the new laws, as a permanent body of regional deputies. ${ }^{111}$

The words zemskii and zemstvo proved important for the continued reforms. During the preparations to the introduction of the zemstvo (zemskoe, "local" or "rural" in this context) self-government on provincial and district levels in parts of the Russian Empire, which was eventually implemented on January 1, 1864, there was a discussion of possible introduction of an empire-wide zemstvo body. In 1863, Minister of Internal Affairs Petr Aleksandrovich Valuev, who briefly employed Shchapov as an expert on Old Believers, ${ }^{112}$ presented the project of a Congress of State Deputies under the State Council to be elected by provincial zemstvo assemblies ${ }^{113}$ and cited the widespread praises to the zemskii sobors of the past in the note which accompanied it. ${ }^{114}$ Although Alexander II rejected the project, the discussions of a possible assembly continued. Among the representatives of the nobility, who advocated the convocation of an assembly since 1858 and mentioned a possible zemskaia duma since 1862, Vladimir Petrovich OrlovDavydov was the first to use the word sobor when speaking of an institution uniting individual zemstvo assemblies in $1865 .{ }^{115}$

The limited character of the reforms stimulated radical opposition. The estateless zemskii sobor became one of the goals of the first Land and Freedom society. ${ }^{116}$ Gertsen argued in 1867 that the convocation of a great sobor without the distinction of classes was the only means to reveal the true needs of the people and overcome the crisis in Russia without a coup, terror, and horror. Gertsen defined the sobor as "the first constituent assembly" or the first parliament, which would mean the freedom of speech and a legal foundation for progress. ${ }^{117}$ Mykhailo Petrovych Drahomanov, who initially supported the reformism of Alexander II, became radicalized during the suppression of the Ukrainian national movement. Supporting the slogans of federalism and decentralization, Drahomanov claimed during the 1877-1878 Russo-Ottoman War in the Balkans that Russia first needed to become a free country, a free federation of Slavs. He called for extending the competence of local self-government through a reform of the zemstvos and for an immediate election of a zemskii sobor, a transitional institution on the way to further reforms. Like for Shchapov and Bakunin, for Drahomanov the local units were the foundation of the future federation, organized in a bottom-up manner. According to Drahomanov, the all-Russian zemskii sobor was expected to 
immediately grant personal freedoms, freedom to all cultural and national groups, and self-government. ${ }^{118}$

The democratic understanding of the zemskii sobor spread within Russia among the members of the zemstvo bodies and in secret organizations. In 1879, Ivan Il'ich Petrunkevich and other zemstvo activists of the Chernigov Province supported the idea of a zemskii sobor. In his program of the zemstvo movement, published the same year, Petrunkevich, however, spoke of a constituent assembly as the movement's goal. ${ }^{119}$ With the spread of the idea of a constituent assembly among the radical opposition, the term zemskii sobor consolidated as its synonym. The revolutionary organization People's Will (Narodnaia volia), formed in 1879, included it in this sense into its program. Its members used the terms constituent assembly, zemskii sobor, and zemskoe sobranie ("the assembly of the land") interchangeably. ${ }^{120}$

New historical interpretations of the zemskii sobor accompanied the political developments. Chicherin, whose 1866 work On Popular Representation became the first major study of parliamentarism in Russian, located Russia in Europe and defined the historical zemskii sobors as estate-representative institutions, which were comparable to their European counterparts. He nevertheless concluded that the geographic conditions, the lack of corporatist foundations and communal self-organization, and the peculiarities of elite development in Russia precluded the sobors' development into a representative institution with political rights. Furthermore, the estate representation, according to Chicherin, was worked out in a top-down manner for organizing the disjointed and mobile population. Connecting his work to contemporary developments and discussing consultative assemblies, Chicherin argued against the revival of irregular assemblies like the Estates General and the zemskii sobors, suggesting that the new political situation demanded permanent institutions. He also maintained that introducing estate assemblies would only have negative consequences. According to Chicherin, it was only after the emancipation of the serfs in 1861 that Russia started to organize the civil life on the principles of "universal liberty and law," the principles which were at the foundation of all European peoples and the precondition for representative institutions. He nevertheless argued against the latter's immediate introduction and in favor of the gradual development of social conditions. ${ }^{121}$

In his 1875 work, Sergeevich continued the comparative studies of the zemskii sobors and European parliaments, finding similarities with the Estates General and the English Parliament in the composition of some sobors. He also concluded that even though it was hard to determine the legal status of the sobors, they were not merely consultative. Sergeevich opposed both the Slavophile idealization of the sobors and their complete dismissal, calling them representative institutions in their embryonic state and deeming them "undoubtedly useful" for the direct communication between the Tsar and the people, which inter alia countered administrative arbitrariness. ${ }^{122}$

The interpretations of the zemskii sobors as part of the gradual political development contributed to the discussions of reforms. When commenting on his project of introducing consultation with local self-government in 1881, Mikhail 
Tarielovich Loris-Melikov mentioned zemskaia duma and zemskii sobor, although he was against the revival of "ancient representation" under the new conditions. ${ }^{123}$

The possible formation of a zemskii sobor of self-government bodies found support among Loris-Melikov's opponents, who rejected constitutionalism. ${ }^{124}$ Rostislav Andreevich Fadeev, a general and a Panslavist author, summarized their ideas in several letters in 1879-1880, first published in 1881. According to Fadeev, the autocratic government had to rely on zemstvo instead of bureaucracy and officers in order to save Russia from "turning into hell." A new, reformed, zemstvo, "organized and closely connected to the government," was supposed to take place of the nobility as the stabilizing "social force" locally. Although Fadeev argued that zemstvo would limit only bureaucracy and not autocracy itself, he suggested that the reform had to be developed locally by the representatives of three social estates - landowners, peasants, and merchants - to be united in provisional consultative committees. Despite the frequent appeals to autocracy, Fadeev's project was that of decentralization, since he expected zemstvo to acquire major fiscal and economic competence. Furthermore, the zemstvo reform was supposed to bring about the convocation of all-Russian consultative zemskii sobors by the government. Relying on Slavophile ideas and appealing to the "zemskii sobors" of the past, Fadeev expected the sobors only to inform the government about local needs, stressed the moral aspects of the proposed system, emphasized that the sobors had little in common with "the European parliament," and firmly rejected a constitution as a contract between the Tsar and the people. ${ }^{125}$ Fadeev's project hence fused autocratic and democratic understandings of the zemskii sobor.

The assassination of Alexander II by the members of the People's Will on March 1, 1881, prevented him from approving Loris-Melikov's consultation reform. During the prosecution of the organization's members in 1882, Aleksandr Dmitrievich Mikhailov, one of them, used the term zemskoe uchreditel'noe sobranie ("the constituent assembly of the land"), which was to be universally elected. Iurii Nikolaevich Bogdanovich, another member of the organization, stressed in his testimony that the people were to decide all major state matters at a zemskii sobor when discussing the program of the People's Will. Other members, however, interpreted the zemskii sobor as an unneeded concession from the government. In 1882, Petr Lavrovich Lavrov opposed the simultaneous demands to convene a zemskii sobor from the government and the attempts to stage a coup against it, arguing that a zemskii sobor of nobles, bureaucrats, merchants, and rich peasants would not defend social interests. ${ }^{126}$

The connection between the terrorists of the People's Will and the zemskii sobor proved important for the public debates, contributing to the rejection of the institution in its Slavophile version, proposed by Ignat'ev, in 1882. Despite the publications by I. S. Aksakov and Golokhvastov, other conservative authors opposed it. Rejecting the idea of a zemskii sobor, Mikhail Nikiforovich Katkov stressed that Andrei Ivanovich Zheliabov, one of the organizers of Alexander II's assassination, and other radicals used it as their slogan. ${ }^{127}$ The Geneva newspaper Vol'noe slovo ("Free Word") (1881-1883), which was edited by Drahomanov and was possibly a government-sponsored organ of a fictitious opposition group, 
continued to use the term zemskii sobor in its more moderate constitutional reform suggestions. ${ }^{128}$ Vladimir Il'ich Lenin was among those who considered the convocation of a zemskii sobor by the government as a means to Russia's political liberation in the 1890 s. ${ }^{129}$

In the $1890 \mathrm{~s}$ and $1900 \mathrm{~s}$, zemstvo activists greatly contributed to the production of the oppositional discourse. According to Ivan Petrovich Belokonskii, a zemstvo employee, the liberal zemstvo opposition consolidated around 1891-1892, agreeing on the need for a "popular representation" (a parliament). In 1895, however, Nicholas II rejected the zemstvos' interest in participation in the government, pledging to defend autocracy. Dmitrii Nikolaevich Shipov, who chaired the Moscow Provincial Zemstvo Administration, nevertheless initiated unofficial congresses of provincial zemstvo heads in 1896. Although the government tried to prevent regular zemstvo congresses, zemstvo activists continued to meet and discuss possible reforms. The more radical part of the liberal opposition, active both in Russia and abroad, opposed a future zemskii sobor in 1903-1904, which some activists proposed, due to its unclear relations to autocracy and unclear membership. Although Shipov supported a consultative zemskii sobor, he continued to partake in the movement which shifted toward constitutionalism. The majority at the unofficial zemstvo congress (also known as the first "legal" one), which took place on November 6-9, 1904, in Saint Petersburg and was chaired by Shipov, supported a legislative "popular representation." 130

Some proponents of terrorism in the Party of Socialists Revolutionaries (formed in 1902) named the convocation of a popular zemskii sobor as the condition for stopping the terror, since it would hold the arbitrariness of the government in check in a peaceful and civilized manner, in the early 1900s. ${ }^{131}$ The more radical left, however, rebuked the slogan. Responding to the assassination of Minister of Internal Affairs Viacheslav Konstantinovich fon Pleve by a Socialist Revolutionary in July 1904, an anarchist group opposed the slogan of a zemskii sobor, claiming that it would simply legalize the dictatorship of the bourgeoisie, and called for the struggle against capital and the state in a proletarian uprising. ${ }^{132}$ In November 1904, an Odessa anarchist-communist group dismissed the promises of "political freedom and a zemskii sobor" by the Socialist Revolutionaries and the Social Democrats, claiming that they would simply replace the autocratic oppression with constitutional and citing the violence against workers in politically free countries. ${ }^{133}$ During the Revolution of 1905-1907, in March 1905, a further anarchist proclamation dismissed the zemskii sobor as a tool of exploitation to be used by the rich, again opposing the Social Democrats. It called for violence against the exploiters and concluded with the slogans against private property and the state. ${ }^{134}$ In April 1905, an anarchist proclamation dismissed the slogans of a zemskii sobor and a constituent assembly, as well as parliamentarism in general, claiming that socialists in a parliament only brought more harm. ${ }^{135}$ The same year, one anarchist group wrote in its proclamation: "Blessed is he who throws a bomb at the zemskii sobor on the first day of its convocation." 136

Interestingly, it was a right-wing author, Sharapov, who returned to the zemskii sobor in the context of decentralization after the introduction of the State Duma. 
Sharapov's 1907 futuristic "political fantasy" Dictator was anti-parliamentary, but it borrowed a lot from the democratic interpretations of the zemskii sobor. In the text, the future dictator of Russia (working under the Tsar) immediately dissolved the State Duma, abolished the new parliamentary system, and announced the convocation of a zemskii sobor, which was to work out the new fundamental laws. Sharapov not only defined the sobor as a constituent body but also suggested that it would divide Russia into large self-governing regions. Furthermore, selfgovernment bodies were supposed to discuss legislation before its final approval by the sobor. ${ }^{137}$ In a way, Sharapov returned to Fadeev's ideas but was more influenced by the democratic understanding of the zemskii sobor.

With the introduction of the State Duma, the zemskii sobor lost its relevance as a democratic slogan. The polemics on the historical sobors, however, continued. In 1905, Ioannikii Alekseevich Malinovskii, for instance, underscored both the development of representation at the sobors in the seventeenth century and the supposed exercise of supreme authority by the 1648-1649 sobor. Citing the works of Sergeevich and Mikhail Flegontovich Vladimirskii-Budanov, Malinovskii claimed that the sobors were not merely consultative and concluded that the sobors proved that the principles of political and civil liberty were not alien to Russia. ${ }^{138}$ Boris Borisovich Glinskii included the zemskii sobors, as a representative institution and a kind of "popular rule" or democracy, into his narrative of the struggle for constitution in a series of articles in 1905-1907. Like Shchapov, he maintained that Peter I destroyed the principle of democracy, noted the recent ban on using the term zemskii sobor in publications, and claimed that the idea survived among those who were dissatisfied with the existing order. ${ }^{139}$

Mikhail Vasil'evich Klochkov did not share such a view on the zemskii sobors in his popular publication in 1905. He acknowledged that historians had previously portrayed the zemskii sobors as "deeply popular" institutions but maintained that the introduction of new sources disenchanted them. Klochkov argued that the zemskii sobors lagged behind Western parliaments, since they were not convened according to law but in line with the desire of the supreme authority, were a primitive form of popular representation, and were hence hardly suitable for Russia at the threshold of a "new, better life."140

The zemskii sobor, however, still had a place in the democratic mythology. Mikhail Vladimirovich Rodzianko, the Chairman of the State Duma, noted in his memoirs that for the official celebrations of the 300th anniversary of House Romanov in 1913, the members of the Duma were assigned places in the back, behind the State Council and the Senate. Rodzianko claimed that he had to tell the organizers of the ceremony that since the celebration had to be a popular festival, one should not have forgotten that in 1613 it was the people in the "Zemskii sobor" and not a group of bureaucrats who elected the Tsar. According to Rodzianko, the argument worked and the organizers made the Senate cede its place to the Duma. ${ }^{141}$

The zemskii sobor as a democratic slogan and a metaphor returned during the Revolution of 1917 and the Civil War of 1918-1922. Interestingly, it was the anarchist Petr Alekseevich Kropotkin who internalized the ironic interpretation of 
the Moscow State Conference of August 1917 as a zemskii sobor and called it the "the sobor of the Russian land," which needed to declare Russia a republic. ${ }^{142}$ In the anticipation of the All-Russian Constituent Assembly, the Old Believer activist Nikolai Petrovich Anufriev published a pamphlet, comparing the "constituent assemblies" of 1613 and 1917. He claimed that the idea of sobor as the way to reestablish authority became part of the popular consciousness during the Time of Troubles and that the sobors were supposed to be permanent due to Mikhail Fedorovich Romanov's minority, representing hence parliamentary statehood in modern terms, but the idea of a people's Tsar failed. Anufriev concluded that the anticipated All-Russian Constituent Assembly could constitute Russia on new principles, similar to the 1613 "Zemskii sobor," but in order to avoid new "troubles" it needed to resolve social problems as well. ${ }^{143}$

The projects of a zemskii sobor emerged both on the left and on the right. According to some sources, Lavr Georgievich Kornilov, the Commander-in-Chief of the Russian Army, whose attempted coup failed in late August 1917, planned to establish a representative body during the anticipated dictatorial regime and to call this body a sobor, possibly a zemskii one. Vasilii Stepanovich Zavoiko, a businessman and one of Kornilov's associates, was allegedly the main advocate of the idea. According to other sources, Zavoiko simply meant the inclusion of the clergy, the Local Council (Sobor) of the Russian Orthodox Church, which assembled on August 15, 1917, into the Extraordinary State Duma, the legislative authority he envisioned. ${ }^{144}$ During the Bolshevik-Left Socialist Revolutionary Coup of October 25-26, 1917, Grigorii Il'ich Shreider, the moderate Socialist Revolutionary Mayor of Petrograd, attempted to rally the opposition around the Committee of Public Safety. In order to strengthen its positions, Shreider initiated the convocation of the "all-Russian zemskii sobor" of zemstvo and municipal self-government bodies, but only representatives of several provinces arrived by November 9, 1917, the planned opening date, and Shreider decided to call it the Conference of Representatives of Local Self-Government instead. ${ }^{145}$

Some participants of the White movement used the constituent assembly and the zemskii sobor as synonymous slogans and rhetorical devices during the Civil War. The government of Aleksandr Vasil'evich Kolchak in Siberia (1918-1920), for instance, refrained from recognizing Finnish independence, claiming that this could only be done by such an assembly. According to the program of the Western Volunteer Army in the Baltic region (1918-1919), the zemskii sobor (the constituent assembly) was supposed to determine the relations of the new postimperial states, fighting the Bolsheviks, with Russia, which in practice allowed it to ignore Latvian independence. In October 1919, the Czechoslovak politician Karel Kramarž proposed his draft Constitution of Russia to Russian émigrés in Paris. The project, which was later discussed in the anti-Bolshevik areas in the south of Russia, proposed a constitutional monarchy or a republic with a Tsar or a president as the head of state. If the system was to become monarchical, then each Tsar was to be elected from the House Romanov by the parliament for life. Explaining this compromise between monarchy and popular sovereignty, Kramarž cited the 300 -year-long tradition dating back to the 1613 assembly. ${ }^{146}$ 
The idea of the zemskii sobor as a democratic institution proved especially prominent in Siberia. On July 7, 1919, Ivan Aleksandrovich Iakushev, a Socialist Revolutionary and Siberian Regionalist, presented a proclamation to the population of Siberia to the Irkutsk Provincial Zemstvo Assembly, calling for the convocation of a zemskii sobor as a parliamentary body. In the fall of 1919, the Socialist Revolutionary zemstvo activists in Irkutsk refused to participate in the State Zemstvo Conference, discussed by the Kolchak government, demanded the convocation of a legislative zemskii sobor instead, and proposed a democratic "buffer" state in Siberia. In November 1919, the Czechoslovak commander Radola Gajda joined Iakushev in organizing an uprising in Vladivostok, which was supposed to end with the convocation of a zemskii sobor, but it was suppressed by Kolchak's subordinates. The Siberian Regionalist Viktor Nikolaevich Pepeliaev, who became Kolchak's Prime Minister later the same month, also called for an immediate convocation of a zemskii sobor. ${ }^{147}$

After the Kolchak government collapsed under the Bolshevik offensive and the successful Socialist Revolutionary coup in Irkutsk in early 1920, it was Zavoiko who proposed a zemskii sobor to the new non-Bolshevik authorities in the Far East. Zavoiko's ideas were close to those of the Siberian Regionalists, as he aspired to start rebuilding Russia by organizing Siberia through a Siberian zemskii sobor. ${ }^{148}$ In 1920, he published a draft Constitution in Japan. The draft pertained only to the Maritime Region but envisioned a reunited Russian federation and reaffirmed the idea of convening a zemskii sobor. It drew heavily on the US Constitution but included conservative elements, such as the elimination of political parties. ${ }^{149}$

When the Priamur Zemskii Sobor was about to convene in Vladivostok in the summer of 1922, there still was no consensus on what the assembly meant, and both the autocratic and democratic mythologies informed the discussions. Indeed, the Socialist Revolutionary slogan of a zemskii sobor as a legislative assembly and its more conservative reinterpretation by Zavoiko were still relevant. According to one account, the Priamur Zemskii Sobor was supposed to elect a provisional national government in order to organize the struggle against the Bolsheviks and build the state, while Diterikhs was the first one in the Vladivostok government to openly call for the restoration of monarchy, breaking with the moderates and aspiring to return to the pre-1905 period when the State Duma had not yet established the "hated constitutional principles." 150

\section{Conclusion}

The political mythologies of the zemskii sobor developed simultaneously with historiography and at times ahead of it. History writing was also a way for some authors to participate in the political debates. The autocratic mythology, promoted by the Slavophiles, proved more coherent yet it did not achieve the desired recognition from the Tsars. Initially, the autocratic approach to the zemskii sobors was idealistic but it became more practical at the summit of its popularity in 1905, when it was discussed by the government as a way to avoid bigger concessions. The democratic mythology was more heterogeneous and, despite occasionally 
fading to the background of the debates, lasted for some hundred years between the 1820s and the 1920s. The idea of zemskii sobor proved influential for the projects of reimagining the empire as a federation, while some radical intellectuals also found the term useful when discussing a constituent assembly. The democratic discourse involved skepticism and criticism of the concept of zemskii sobor from the onset of the discussions, with many moderates becoming disillusioned with it, but the concept survived as part of the romantic nationalist imagery and flourished as a symbol during the Civil War, with the zemskii sobor being imagined as a Russian constituent assembly, destined to mend the new Time of Troubles. The two mythologies were not isolated and overlapped in several projects, including the Priamur Zemskii Sobor of 1922.

Both mythologies lived on after the empire's collapse. In 1964, the Supreme sobor as a "controlling" branch from the project by Pestel' reemerged in the outline of a Constitution proposed by a group of right-wing dissidents. With the clergy anticipated to play a major role in it, the new version of the Supreme sobor was supposed to remind of the historical assemblies and embodied religious nationalism. ${ }^{151}$ In 1990, Aleksandr Isaevich Solzhenitsyn, the most prominent conservative dissident writer, quoted Shipov on the zemskii sobors and claimed that there had been no struggle between the Tsar and the people, very much like the Slavophiles. He also proposed a possible body, a sobornaia duma or a state duma, consisting of esteemed individuals with high morals, wisdom, and life experience as part of Russia's future system of government. ${ }^{152}$

The democratic mythology informed the debates on the new Russian Constitution in 1993. The Russian Social-Ecological Union, a major environmental association, included the sobors into its proposals on Russia's federal system, which it submitted to the Constitutional Commission. Russia was to be divided into lands, and the zemel'nyi sobor ("the assembly of the land") was to be the supreme legislature of each land, which was reminiscent of both Murav'ev's and Shchapov's ideas. ${ }^{153}$ The nationalist Sergei Petrovich Pykhtin authored an alternative draft Constitution, in which the Zemskii sobor was the legislative body consisting of three chambers: the State Duma, the Senate, and the State Council. The former two chambers were to be universally elected. The whole Zemskii sobor elected the President without debates for a five-year term. Although this project used the language of the imperial bureaucracy and the right-wing intellectuals, in essence it represented a modern democratic system, despite the election of the President without debate ${ }^{154}$ and once again demonstrated a fusion of democratic and autocratic mythologies of the zemskii sobor.

\section{Notes}

1 This study was completed as part of the project "ENTPAR: Entangled Parliamentarisms: Constitutional Practices in Russia, Ukraine, China and Mongolia, 1905-2005," which received funding from the European Research Council (ERC) under the European Union's Horizon 2020 research and innovation program (grant agreement no. 755504).

2 Peter B. Brown, "The 'Zemskii Sobor' in Recent Soviet Historiography," Russian History 10, no. 1 (1983): 90. 
3 For a poststructuralist approach to the Russian Empire and imperial parliamentarism, see Ilya Gerasimov et al., "New Imperial History and the Challenges of Empire," in Empire Speaks Out: Languages of Rationalization and Self-Description in the Russian Empire, eds. Ilya Gerasimov, Jan Kusber, and Alexander Semyonov (Leiden: Brill, 2009), 3-32; Alexander Semyonov, “"The Real and Live Ethnographic Map of Russia': The Russian Empire in the Mirror of the State Duma," in Empire Speaks Out: Languages of Rationalization and Self-Description in the Russian Empire, eds. Ilya Gerasimov, Jan Kusber, and Alexander Semyonov (Leiden: Brill, 2009), 191-228.

4 Nancy Shields Kollmann, By Honor Bound: State and Society in Early Modern Russia (Ithaca, NY: Cornell University Press, 1999), 169; Valerie Kivelson, "Muscovite 'Citizenship': Rights without Freedom," The Journal of Modern History 74, no. 3 (2002): 467-468.

5 Quentin Skinner, Visions of Politics, vol. 1: Regarding Method (Cambridge: Cambridge University Press, 2002), 4-5; Jakob Norberg, "Concepts, Political," in The Encyclopedia of Political Thought, eds. Michael T. Gibbons et al., vol. 2 (Malden, MA: Wiley-Blackwell, 2015), 647-657.

6 Serhiy Bilenky, Romantic Nationalism in Eastern Europe: Russian, Polish, and Ukrainian Political Imaginations (Stanford, CA: Stanford University Press, 2012); Susanna Rabow-Edling, "The Decembrists and the Concept of a Civic Nation," Nationalities Papers 35, no. 2 (2007): 369-391.

7 Dimitri Von Mohrenschildt, Toward a United States of Russia: Plans and Projects of Federal Reconstruction of Russia in the Nineteenth Century (London: Associated University Presses, 1981), 63-65, 242; Richard S. Wortman, Scenarios of Power: Myth and Ceremony in Russian Monarchy from Peter the Great to the Abdication of Nicholas II (Princeton, NJ: Princeton University Press, 2006), 246, 269-270, 361-362.

8 Valerie A. Kivelson, "On Words, Sources, and Historical Method: Which Truth about Muscovy?," Kritika: Explorations in Russian and Eurasian History 3, no. 3 (2002): 487-499.

9 Illarion, "Slovo o Zakone i Blagodati [Excerpts, 1030s-1050s]," in Russkaia Sotsial'no-Politicheskaia Mysl'XI-XVII Vv.: Khrestomatiia, eds. S. V. Perevezentsev et al. (Moscow: Izdatel'stvo Moskovskogo universiteta, 2011), 28-29.

10 V. Panov and V. Lebedev, eds., "Kievskaia Letopis'," in Drevnerusskie Letopisi (Moscow: Academia, 1936), 123.

11 L. V. Cherepnin claimed that the term zemskii sobor was not mentioned in the documents of the sixteenth century and was "rarely" used in the documents of the seventeenth century but did not cite the concrete uses of the term, see L. V. Cherepnin, Zemskie Sobory Russkogo Gosudarstva v XVI-XVII Vv. (Moscow: Nauka, 1978), 63.

12 R. G. Skrynnikov, Ivan Groznyi (Moscow: Nauka, 1983), 33.

13 S. V. Perevezentsev et al., eds., "Slovo Tsaria Ivana IV Vasil'evicha na Stoglavom Sobore 1551 Goda," in Russkaia Sotsial'no-Politicheskaia Mysl' XI-XVII Vv.: Khrestomatiia (Moscow: Izdatel'stvo Moskovskogo universiteta, 2011), 241-242.

14 Iu. V. Got'e, ed., Akty, Otnosiashchiesia k Istorii Zemskikh Soborov (Moscow: Izdanie N. N. Klochkova, 1909), 1-13, 16-17, 19, 21, 24, 26, 30, 34, 37, 64-65, 68-69; S. A. Belokurov, ed., Utverzhdennaia Gramota Ob Izbranii Na Moskovskoe Gosudarstvo Mikhaila Fedorovicha Romanova, 2nd ed. (Moscow: Sinoidal'naia tipografiia, 1906), 43.

15 N. M. Karamzin, Istoriia Gosudarstva Rossiiskogo, vol. 10 (Saint Petersburg: Tipografiia N. Grecha, 1824), 8, 227-232; N. M. Karamzin, Istoriia Gosudarstva Rossiiskogo, vol. 12 (Saint Petersburg: Tipografiia N. Grecha, 1829), 145, 310, 317.

16 Karamzin, Istoriia Gosudarstva Rossiiskogo, 1824, 10:75.

17 The Slavophiles were the group of Russian intellectuals who insisted on the uniqueness of Russia's history and opposed the country's Westernization. They are usually juxta- 


\section{Ivan Sablin and Kuzma Kukushkin}

posed with the Westernizers, see Bilenky, Romantic Nationalism in Eastern Europe: Russian, Polish, and Ukrainian Political Imaginations, 207.

18 The term zemskii sobor is mentioned only once in A. S. Khomiakov's tragedy Dmitrii the Impostor, while the term zemskaia duma ("the Council of the Land") is used three times for, apparently, the same type of assembly, see A. S. Khomiakov, "Dmitrii Samozvanets: Tragediia [1833]," in Polnoe Sobranie Sochinenii, 3rd ed., vol. 4 (Moscow: Universitetskaia tipografiia, 1900), 128, 154-155, 172. He again used the term zemskii sobor in a 1844 article on Mikhail Ivanovich Glinka's opera A Life for the Tsar, discussing its setting during the Time of Troubles, see A. S. Khomiakov, “Opera Glinki 'Zhizn' za Tsaria' [1844]," in Polnoe Sobranie Sochinenii, 3rd ed., vol. 3 (Moscow: Universitetskaia tipografiia, 1900), 100.

19 S. L. Avaliani, Zemskie Sobory: Literaturnaia Istoriia Zemskikh Soborov (Odessa: A. A. Ivasenko, 1916), 5-6.

20 Avaliani, Zemskie Sobory.

21 S. F. Platonov, "Moskovskie Zemskie Sobory XVI o XVII Vekov [1881-1882]," in Sobranie Sochinenii, eds. S. O. Shmidt, V. V. Morozov, and A. V. Sirenov, vol. 1 (Moscow: Nauka, 2010), 29-30, 42, 174.

22 Avaliani, Zemskie Sobory, 82-88; V. O. Kliuchevskii, "Sostav Predstavitel'stva Na Zemskikh Soborakh Drevnei Rusi (Posviashchaetsia B. N. Chicherinu) [1890-1892]," in Sochineniia, ed. V. L. Ianin, vol. 8 (Moscow: Mysl', 1990), 277-374.

23 M. N. Pokrovskii, Russkaia Istoriia [1909-1914], vol. 1 (Saint Petersburg: Poligon, 2002), 340-345.

24 M. N. Pokrovskii, “Kak i Kem Pisalas' Russkaia Istoriia do Marksistov [1920],” in Izbrannye Proizvedeniia, eds. M. N. Tikhomirov et al., vol. 3 (Moscow: Mysl', 1967), 242.

25 The term narodnoe predstavitel'stvo was frequently used for a parliament since the second half of the nineteenth century.

26 K. M. Takhtarev, Obshchestvo i Gosudarstvo i Zakon Bor'by Klassov (Petrograd: Kniga, 1918), 110-113.

27 P. Stuchka and N. Cheliapov, eds., "Deputat," in Entsiklopediia Gosudarstva i Prava, vol. 1 (Moscow: Izdatel'stvo kommunisticheskoi akademii, 1925), 846.

28 N. L. Meshcheriakov, ed., Malaia Sovetskaia Entsiklopediia, vol. 5 (Moscow: Sovetskaia entsiklopediia, 1930), 331; S. I. Vavilov et al., eds., Bol'shaia Sovetskaia Entsiklopediia, vol. Soiuz Sovetskikh Sotsialisticheskikh Respublik (Moscow: OGIZ, 1947), 287, 363, 370, 387.

29 Cherepnin, Zemskie Sobory Russkogo Gosudarstva v XVI-XVII Vv., 3-4; R. G. Skrynnikov, Rossiia Nakanune "Smutnogo Vremeni” (Moscow: Mysl', 1981), 10-16, 123-150; Skrynnikov, Ivan Groznyi, 105-106, 193-194; A. A. Zimin, Oprichnina Ivana Groznogo (Moscow: Mysl', 1964), 364-365, 369-370.

30 Brown, "The 'Zemskii Sobor' in Recent Soviet Historiography," 78, 83-90. Brown dismisses the assemblies between 1653 and 1684 as zemskii sobors, see Cherepnin, Zemskie Sobory Russkogo Gosudarstva v XVI-XVII Vv., 368.

31 Thomas Munck, however, admitted that the social structure of Muscovy and Russia was too different from other European states, and there was no reliable information on the membership of the sobors, see Thomas Munck, Seventeenth Century Europe 1598-1700 (Macmillan: London, 1990), x, 8, 32-33.

32 Donald Ostrowski, "The Assembly of the Land (Zemskii Sobor) as a Representative Institution," in Modernizing Muscovy: Reform and Social Change in SeventeenthCentury Russia, eds. Jarmo Kotilaine and Marshall Poe (London: RoutledgeCurzon, 2004), 111-136.

33 Marshall Poe, "The Truth about Muscovy," Kritika: Explorations in Russian and Eurasian History 3, no. 3 (2002): 482.

34 Sergei Bogatyrev, "Ivan IV (1533-1584)," in The Cambridge History of Russia, ed. Maureen Perrie, vol. 1: From early Rus' to 1689 (Cambridge: Cambridge University Press, 2006), 259. 
35 Endre Sashalmi, "God Is High Up, the Tsar Is Far Away: The Nature of Polity and Political Culture in 17th-Century Russia," in Empowering Interactions: Political Cultures and the Emergence of the State in Europe, 1300-1900, eds. Willem Pieter Blockmans et al. (Farnham: Ashgate, 2009), 147.

36 Brian Davies, "Local Government and Administration," in The Cambridge History of Russia, ed. Maureen Perrie, vol. 1: From early Rus' to 1689 (Cambridge: Cambridge University Press, 2006), 469.

37 Chester S. L. Dunning, A Short History of Russia's First Civil War: The Time of Troubles and the Founding of the Romanov Dynasty (University Park, PA: Pennsylvania State University Press, 2001), 139, 162, 285-286, 304-306.

38 Devid Griffits, "Zhalovannye Gramoty Ekateriny II Dvorianstvu i Gorodam 1785 Goda: O Sosloviiakh, Gramotakh, Konstitutsiiakh," in Ekaterina II i Ee Mir: Stat'i Raznykh Let, eds. M. Lavrinovich and I. Fediukin (Moscow: Novoe literaturnoe obozrenie, 2013), 190-250.

39 Ekaterina II, "Nakaz Komissii o Sostavlenii Proekta Novogo Ulozheniia [1767]," in Konstitutsionnye Proekty v Rossii XVIII - Nachala XX Veka, ed. A. N. Medushevskii (Moscow: ROSSPEN, 2010), 149.

40 Valerie A. Kivelson, Autocracy in the Provinces: The Muscovite Gentry and Political Culture in the Seventeenth Century (Stanford, CA: Stanford University Press, 1996), 13. Endre Sashalmi articulated the same argument, see Sashalmi, "God Is High Up, the Tsar Is Far Away: The Nature of Polity and Political Culture in 17th-Century Russia," 138.

41 Ostrowski, "The Assembly of the Land (Zemskii Sobor) as a Representative Institution."

42 Chester S. L. Dunning, Russia 's First Civil War: The Time of Troubles and the Founding of the Romanov Dynasty (University Park, PA: Pennsylvania State University Press, 2010), 298-299.

43 M. M. Krom, Rozhdenie Gosudarstva: Moskovskaia Rus' XV-XVI Vekov (Moscow: Novoe literaturnoe obozrenie, 2018), 155-159.

44 Richard Hellie, "Thoughts on the Absence of Elite Resistance in Muscovy," Kritika: Explorations in Russian and Eurasian History 1, no. 1 (2000): 9-10.

45 I. O. Tiumentsev, "Iz Istorii Sozdaniia 'Istorii' Avraamiia Palitsyna," in Trudy Otdela Drevnerusskoi Literatury, ed. O. V. Tvorogov, vol. 57 (Saint Petersburg: Dmitrii Bulanin, 2006), 242-244.

46 Belokurov, Utverzhdennaia Gramota ob Izbranii na Moskovskoe Gosudarstvo Mikhaila Fedorovicha Romanova, 42-47.

47 S. F. Platonov and P. G. Vasenko, "Novyi Letopisets," vol. 14, Part I (Saint Petersburg: Tipografiia M. A. Aleksandrova, 1910), 128-129.

48 L. V. Cherepnin, O. A. Derzhavina, and E. V. Kolosova, eds., Skazanie Avraamiia Palitsyna (Moscow: Izd-vo AN SSSR, 1955), 231-232.

49 M. V. Kaplun, "K Voprosu o Zapadnoevropeiskikh Istokakh Pervykh Russkikh Komedii (Po Materialam Posol'skogo Prikaza Vtoroi Poloviny XVII V.)," Vestnik Tomskogo Gosudarstvennogo Universiteta, no. 451 (2020): 30.

50 Komissiia pechataniia gosudarstvennykh gramot i dogovorov, sostoiashchaia pri Moskovskom glavnom arkhive Ministerstva inostrannykh del, Kniga ob Izbranii Na Tsarstvo Velikogo Gosudaria, Tsaria i Velikogo Kniazia Mikhaila Fedorovicha (Moscow: Sinoidal'naia tipografiia, 1856), iii-iv, xxxvi-xxxvii, 8-13.

51 Karamzin, Istoriia Gosudarstva Rossiiskogo, 1824, 10:11, 232.

52 Karamzin, Istoriia Gosudarstva Rossiiskogo, 1829, 12:310, 313.

53 A. S. Khomiakov, "O Starom i Novom [1839]," in Polnoe Sobranie Sochinenii, 3rd ed., vol. 3 (Moscow: Universitetskaia tipografiia, 1900), 14.

54 K. S. Aksakov, "Kratkii Istoricheskii Orcherk Zemskikh Soborov: Predislovie [Early 1850s]," in Polnoe Sobranie Sochinenii, ed. I. S. Aksakov (Moscow: Tipografiia P. Bakhmeteva, 1861), 291-292, 295-296; Bilenky, Romantic Nationalism in Eastern Europe: Russian, Polish, and Ukrainian Political Imaginations, 207. 


\section{Ivan Sablin and Kuzma Kukushkin}

55 M. O. Gershenzon, "Slavianofil'stvo," in Slavianofil'stvo: Pro et Contra, eds. V. A. Fateev and D. K. Burlaka (Saint Petersburg: Izd-vo S.-Peterb. un-ta, 2009), 687.

56 K. S. Aksakov, 'Zapiska 'O Vnutrennem Sostoianii Rossii,' Predstavlennaia Gosudariu Imperatoru Aleksandu II v 1855 G.," in Russkaia Sotsial'no-Politicheskaia Mysl', 1850-1860-e Gody: Khrestomatiia, eds. A. A. Shiriniants et al. (Moscow: Izdatel'stvo Moskovskogo universiteta, 2012), 64-65, 74-76.

57 Komissiia, Kniga ob Izbranii na Tsarstvo, ii-iii.

58 D. A. Badalian, "Poniatie 'Zemskii Sobor' i Predstavleniia o Vlasti v Rossii XIX Veka: Ot Karamzina Do Stepniaka-Kravchinskogo,” Tetradi Po Konservatizmu, no. 4 (2018): 149.

59 I. V. Beliaev, Tsar' i Velikii Kniaz' Ioann IV Vasil'evich Groznyi, Moskovskii i Vseia Rusi (Moscow: Universitetskaia tipografiia, 1866), 14.

60 I. D. Beliaev, Zemskie Sobory Na Rusi (Rech' Chitannaia 12-go Ianvaria 1867 Goda na Torzhestvennom Akte) (Moscow: Universitetskaia tipografiia, 1867), 1-2, 6-8.

61 K. D. Kavelin, "Mysli o Vybornom Nachale [1874]," in Politicheskie Instituty, Izbiratel'noe Pravo i Protsess v Trudakh Rossiiskikh Myslitelei XIX-XX Vekov, eds. I. $B$. Borisov et al. (Moscow: Tsentral'naia izbiratel'naia komissiia Rossiiskoi Federatsii, 2008), 371.

62 Badalian, "Poniatie 'Zemskii Sobor' i Predstavleniia o Vlasti v Rossii XIX Veka," 150.

63 V. E. Andreev, "Semeinyi Konflikt (k Voprosu o Vzaimootnosheniiakh Imperatora Aleksandra III i Velikogo Knizia Konstantina Nikolaevicha)," in Aleksandr III: Pro et Contra, eds. I. E. Barykina and V. G. Chernukha (Saint Petersburg: RKhGA, 2013), 430.

64 V. G. Chernukha, "Aleksandr III (1845-1894)," in Aleksandr III: Pro et Contra, eds. I. E. Barykina and V. G. Chernukha (Saint Petersburg: RKhGA, 2013), 35; A. A. Kornilov, "Kurs Istorii Rossii XIX Veka [Excerpt]," in Aleksandr III: Pro et Contra, eds. I. E. Barykina and V. G. Chernukha (Saint Petersburg: RKhGA, 2013), 660, 675; D. A. Badalian, "Polemika o Zemskom Sobore v Russkoi Presse Nachala 1880-Kh Godov," Trudy Sankt-Peterburgskogo Gosudarstvennogo Instituta Kul'tury 201 (2013): 28-31.

65 A. A. Kireev, "Slavianofil'stvo i Natsionalizm: Otvet V. S. Solov'evu [Excerpts, 1889]," in Slavianofil'stvo: Pro et Contra, eds. V. A. Fateev and D. K. Burlaka (Saint Petersburg: Izd-vo S.-Peterb. un-ta, 2009), 520-521.

66 L. A. Tikhomirov, "Rabochii Vopros i Russkie Idealy [1902]," in Konservatizm: Pro et Contra, eds. A. Ia. Kozhurin, A. A. Sinitsyn, and D. K. Bogatyrev (Saint Petersburg: RKhGA, 2016), 488-489.

67 Wortman, Scenarios of Power: Myth and Ceremony in Russian Monarchy from Peter the Great to the Abdication of Nicholas II, 361-362.

68 L. L'vov [L. M. Kliachko], Za Kulisami Starogo Rezhima: Vospominaniia Zhurnalista, vol. 1 (Leningrad: Gosudarstvennaia tipografiia, 1926), 105-106; I. V. Lukoianov, ed., "Perepiska A. A. Kireeva i F. D. Samarina," Nestor, no. 3 (2000): 13-14; I. V. Omel'ianchuk, "Narodnoe Predstavitel'stvo v Ideologii Rossiiskikh Konservatorov Nachala XX Veka," in Tavricheskie Chteniia 2013: Aktual'nyeproblemy Parlamentarizma: Istoriia $i$ Sovremennost': Mezhdunarodnaia Nauchnaia Konferentsiia, S.-Peterburg, Tavricheskii Dvoretst, 11-12 Dekabria 2013 G.: Sbornik Nauchnykh Statei, ed. A. B. Nikolaev, vol. 1 (Saint Petersburg: ElekSis, 2014), 46.

69 N. N. Mazurenko, Vserossiiskie Zemskie Sobory: Istoricheskii Ocherk (Saint Petersburg: Tipografiia imperatorskogo chelovekoliubivogo obshchestva, 1905), 4, 48-49.

70 Lukoianov, "Perepiska A. A. Kireeva i F. D. Samarina," 12.

71 Omel'ianchuk, "Narodnoe Predstavitel'stvo v Ideologii Rossiiskikh Konservatorov Nachala XX Veka," 47-48.

72 Lukoianov, "Perepiska A. A. Kireeva i F. D. Samarina," 15-18, 23.

73 S. S. Ol'denburg, Tsarstvovanie Imperatora Nikolaia II, vol. 1 (Belgrade: Izdanie Obshchestva Rasprostraneniia Russkoi Natsional'noi i Patrioticheskoi Literatury, 1939), 272-273; Lukoianov, "Perepiska A. A. Kireeva i F. D. Samarina," 19-23.

74 Lukoianov, "Perepiska A. A. Kireeva i F. D. Samarina," 24-27. 
75 Iu. I. Kir'ianov, ed., Pravye Partii, 1905-1917 Gg.: Dokumenty i Materialy, vol. 1: 1905-1910 gg. (Moscow: ROSSPEN, 1998), 82-83.

76 Kir'ianov, 1: 1905-1910 gg.:138.

77 A. N. Arinin and V. V. Shelokhaev, eds., Prava i Svobody Cheloveka v Programmnykh Dokumentakh Osnovnykh Politicheskikh Partii i Ob"edinenii Rossii, XX Vek (Moscow: ROSSPEN, 2002), 40.

78 S. F. Sharapov, "Rossiia Budushchego (Tret'e Izdanie 'Opyta Russkoi Politicheskoi Programmy') [1907]," in Izbrannoe, ed. A. V. Repnikov (Moscow: ROSSPEN, 2010), 56.

79 S. F. Sharapov, "Russkie Istoricheskie Nachala i Ikh Sovremennoe Prilozheniie [1907]," in Izbrannoe, ed. A. V. Repnikov (Moscow: ROSSPEN, 2010), 338.

80 Omel'ianchuk, "Narodnoe Predstavitel'stvo v Ideologii Rossiiskikh Konservatorov Nachala XX Veka," 49-50.

81 P. A. Pozhigailo, P. A. Stolypin: Grani Talanta Politika (Moscow: ROSSPEN, 2012), 156.

82 Iu. I. Kir'ianov, ed., Pravye Partii, 1905-1917 Gg.: Dokumenty i Materialy, vol. 2: 1911-1917 Gg. (Moscow: ROSSPEN, 1998), 217.

83 Omel'ianchuk, "Narodnoe Predstavitel'stvo v Ideologii Rossiiskikh Konservatorov Nachala XX Veka," 51.

84 Iaroslavskaia Uchenaia Arkhivnaia Komissiia, Izbranie na Tsarstvo Mikhaila Feodorovicha, 1613-1913 Gg. (Yaroslavl: Tipo-litografiia Nikolaevo zd. Sin. Monastyria, 1913), 3-4.

85 D. V. Tsvetaev, Izbranie Mikhaila Feodorovicha Romanova na Tsarstvo (Moscow: T-vo skoropechatni A. A. Levenson, 1913), 5-7.

86 Z. Galili, A. Nenarokov, and L. Kheimson, eds., Men 'sheviki v 1917 Godu, vol. 2: Ot Iiul'skikh Sobytii do Kornilovskogo Miatezha (Moscow: Progress-Akademiia, 1995), 133-134.

87 Ivan Sablin, The Rise and Fall of Russia's Far Eastern Republic, 1905-1922: Nationalisms, Imperialisms, and Regionalisms in and after the Russian Empire (London: Routledge, 2018), 234, 247-248.

88 Sablin, 248, 250-252; Wortman, Scenarios of Power: Myth and Ceremony in Russian Monarchy from Peter the Great to the Abdication of Nicholas II, 282-302.

89 Rabow-Edling, "The Decembrists and the Concept of a Civic Nation."

90 N. I. Tarabasova et al., eds., Vesti-Kuranty: 1600-1639 Gg. (Moscow: Nauka, 1972), 42, 47, 69, 76-77, 88-90, 102, 112-115, 182-183; N. I. Tarabasova, V. G. Dem'ianov, and S. I. Kotkov, eds., Vesti-Kuranty: 1645-1646, 1648 Gg. (Moscow: Nauka, 1980), 95-96, 159; Ingrid Maier, "Newspaper Translations in SeventeenthCentury Muscovy: About the Sources, Topics and Periodicity of Kuranty 'Made in Stockholm' (1649)," in Explorare Necesse Est Hyllningsskrift till Barbro Nilsson, eds. Per Ambrosiani et al. (Stockholm: Almqvist \& Wiksell International, 2002), 181-190; Ingrid Maier and Stepan Shamin, “'Revolts' in the Kuranty of MarchJuly 1671," in From Mutual Observation to Propaganda War: Premodern Revolts in Their Transnational Representations, ed. Malte Griesse (Bielefeld: Transcript Verlag, 2014), 181-204.

91 A. N. Medushevskii, ed., "Konditsii, Soderzhashchie Ogranichenie Vlasti Monarkha v Pol'zu Verkhovnogo Tainogo Soveta, 19 Ianvaria 1730 G.," in Konstitutsionnye Proekty v Rossii XVIII - Nachala XX Veka (Moscow: ROSSPEN, 2010), 76; N. I. Panin, "Proekt Manifesta o Reforme Senata i Sozdanii Imperatorskogo Soveta, 28 Dekabria 1762 G.," in Konstitutsionnye Proekty v Rossii XVIII - Nachala XX Veka, ed. A. N. Medushevskii (Moscow: ROSSPEN, 2010), 137.

92 I. V. Kurukin, Epokha “Dvorskikh Bur'”': Ocherki Politicheskoi Istorii Poslepetrovskoi Rossii, 1725-1762 Gg. (Ryazan: Chastnyi izdatel' P. A. Tribunskii, 2003), 169, 195.

93 M. M. Speranskii, "Vvedenie k Ulozheniiu Gosudarstvennykh Zakonov [1809]," in Konstitutsionnye Proekty v Rossii XVIII - Nachala XX Veka, ed. A. N. Medushevskii (Moscow: ROSSPEN, 2010), 220, 244-248. 


\section{Ivan Sablin and Kuzma Kukushkin}

94 V. V. Leontovich, Istoriia Liberlizma v Rossii, 1762-1914 (Paris: YMCA-PRESS, 1980), 83.

95 "Ustawa Konsytuctjna Królestwa Polskiego z Dnia 27 Listopada 1815 r.," Biblioteka Sejmowa, accessed 19 November 2019, http://libr.sejm.gov.pl/tek01/txt/kpol/1815-r0 .html; N. N. Novosil'tsev, "Gosudarstvennaia Gramota Rossiskoi Imperill [1820]," in Konstitutsionnye Proekty v Rossii XVIII - Nachala XX Veka, ed. A. N. Medushevskii (Moscow: ROSSPEN, 2010), 270, 283.

96 Karamzin, Istoriia Gosudarstva Rossiiskogo, 1824, 10:8, 75.

97 Karamzin, Istoriia Gosudarstva Rossiiskogo, 1829, 12:145.

98 Ibid., 241.

99 Ibid., 310-313.

100 N. M. Murav'ev, "Konstitutsionnyi Proekt [1825]," in Konstitutsionnye Proekty $v$ Rossii XVIII - Nachala XX Veka, ed. A. N. Medushevskii (Moscow: ROSSPEN, 2010), 313, 320-321; N. M. Murav'ev, "Konstitutsiia [1825]," in Russkaia Sotsial'no-Politicheskaia Mysl', Pervaia Polovina XIX Veka: Khrestomatiia, eds. A. A. Shiriniants et al. (Moscow: Izdatel'stvo Moskovskogo universiteta, 2011), 162164, 166, 170; P. I. Pestel', “'Russkaia Pravda' [1825]," in Konstitutsionnye Proekty $v$ Rossii XVIII - Nachala XX Veka, ed. A. N. Medushevskii (Moscow: ROSSPEN, 2010), 330; Badalian, "Poniatie 'Zemskii Sobor' i Predstavleniia o Vlasti v Rossii XIX Veka," 141.

101 V. G. Belinskii, "Otvet 'Moskvitianinu' [Excerpts, 1847]," in Slavianofil'stvo: Pro et Contra, eds. V. A. Fateev and D. K. Burlaka (Saint Petersburg: Izd-vo S.-Peterb. un-ta, 2009), 253-255.

102 K. N. Bestuzhev-Riumin, "Slavianofil'skoe Uchenie i Ego Sud'ba v Russkoi Literature [Excerpts, 1862]," in Slavianofil'stvo: Pro et Contra, eds. V. A. Fateev and D. K. Burlaka (Saint Petersburg: Izd-vo S.-Peterb. un-ta, 2009), 343-344.

103 Von Mohrenschildt, Toward a United States of Russia: Plans and Projects of Federal Reconstruction of Russia in the Nineteenth Century, 64-65.

104 A. P. Shchapov, "Obshchii Vzgliad Na Istoriiu Velikorusskogo Naroda: Vstupitel'naia Lektsiia v Kazanskom Universitete 12 Noiabria 1860 Goda,” ed. E. I. Chernyshev, Izvestiia Obshchestva Arkheologii, Istorii i Etnografii Pri Kazanskom Universitete 33, no. 2-3 (1926): 18, 22, 26-27.

105 A. P. Shchapov, “Pis'mo Aleksandru II [1861]," Krasnyi Arkhiv 6, no. 19 (1926): 162.

106 M. V. Nechkina, ed., "A. P Shchapov v Gody Revoliutsionnoi Situatsii: Pis'mo k P. P. Viazemskomu Ot 8 Okriabria 1861 G.," Literaturnoe Nasledstvo 67 (1959): 658, 661-662.

107 Badalian, "Poniatie 'Zemskii Sobor' i Predstavleniia o Vlasti v Rossii XIX Veka," 146.

108 Nechkina, “A. P Shchapov v Gody Revoliutsionnoi Situatsii," 648, 656.

109 A. I. Gertsen, "P. A. Mart'ianov i Zemskii Tsar' [1864]," in Sobranie Sochinenii v Tridtsati Tomakh, ed. V. P. Volgin, vol. 18 (Moscow: Izdatel'stvo Akademii nauk SSSR, 1959), 11-13, 528-529; Badalian, "Poniatie 'Zemskii Sobor' i Predstavleniia o Vlasti v Rossii XIX Veka," 146-147.

110 Kolokol, January 1, 1861: 748, 751.

111 Badalian, "Poniatie 'Zemskii Sobor' i Predstavleniia o Vlasti v Rossii XIX Veka," 147-148.

112 G. D. Gloveli, “Afanasii Shchapov - Istorik Rossiiskoi Tsivilizatsii,” Federalizm, no. 2 (62) (2011): 173.

113 P. A. Valuev, "Proekt Reformy Gosudarstvennogo Soveta [1863]," in Konstitutsionnye Proekty v Rossii XVIII - Nachala XX Veka, ed. A. N. Medushevskii (Moscow: ROSSPEN, 2010), 409.

114 P. A. Valuev, "Zapiska Aleksandru II o Proekte Reformy Gosudarstvennogo Soveta, 13 Aprelia 1863 G.," in Konstitutsionnye Proekty v Rossii XVIII - Nachala XX Veka, ed. A. N. Medushevskii (Moscow: ROSSPEN, 2010), 403. 
115 Badalian, "Poniatie 'Zemskii Sobor' i Predstavleniia o Vlasti v Rossii XIX Veka," $150-151$.

116 L. F. Panteleev, Vospominaniia, ed. S. A. Resiner (Moscow: Gosudarstvennoe izdatel'stvo khudozhestvennoi literatury, 1958), 7-8.

117 A. I. Gertsen, "Prolegomena [1867]," in Sochineniia v Dvukh Tomakh, eds. Z. V. Smirnova and A. I. Volodin, vol. 2 (Moscow: Mysl', 1986), 524-525.

118 Von Mohrenschildt, Toward a United States of Russia, 144, 242; Mikhail Bakunin, "Federalism, Socialism, Anti-Theologism (1867)," in Bakunin on Anarchy: Selected Works by the Activist-Founder of World Anarchism, ed. Sam Dolgoff (New York: Vintage Books, 1972), 102-147.

119 Badalian, "Poniatie 'Zemskii Sobor' i Predstavleniia o Vlasti v Rossii XIX Veka," 150.

120 M. D. Trukhin, "Ideia Uchreditel'nogo Sobraniia v Vozzreniiakh Liderov Revol'iutsionnoi Organizatsii 'Narodnaia Volia'," Vestnik Moskovskogo Gosudarstvennogo Oblastnogo Universiteta: Seriia "Istoriia i Politicheskie Nauki," no. 5 (2012): 101; M. D. Trukhin, "Ideia Uchreditel'nogo Sobraniia vo Vzgliadakh Chlenov Revol'iutsionnoi Organizatsii 'Narodnaia Volia' L. A. Tikhomirova i N. A. Morozova," Vestnik Moskovskogo Gosudarstvennogo Oblastnogo Universiteta: Seriia "Istoriia i Politicheskie Nauki," no. 3 (2014): 90.

121 B. N. Chicherin, O Narodnom Predstavitel'stve (Moscow: Tipografiia Gracheva i Komp., 1866), 96-97, 126, 355-362, 381-382.

122 V. I. Sergeevich, "Zemskie Sobory v Moskovskom Gosudarstve," in Sbornik Gosudarstvennykh Znanii, ed. V. P. Bezobrazov, vol. 2 (Saint Petersburg: Izd. D. E. Kozhanchikova, 1875), 14-15, 35-36, 40, 55.

123 M. T. Loris-Melikov, "Doklad o Privlechenii Predstavitelei Naseleniia k Zakonosoveshchatel'noi Deiatel'nosti, 28 Ianvaria 1881 G.," in Konstitutsionnye Proekty v Rossii XVIII - Nachala XX Veka, ed. A. N. Medushevskii (Moscow: ROSSPEN, 2010), 468.

124 B. V. Anan'ich and R. Sh. Ganelin, "S. Iu. Vitte, M. P. Dragomanov i 'Vol'noe Slovo' (Po Povodu Odnogo Dokumenta iz Arkhiva M. K. Lemke)," in Trudy Leningradskogo Otdeleniia Instituta Istorii, ed. N. E. Nosov, vol. 7: Issledovaniia po otechestvennomu istochnikovedeniiu: Sbornik statei, posviashchennyi 75-letiiu prof. S. N. Valka (Leningrad: Nauka, 1964), 172-173.

125 R. A. Fadeev, Pis'ma o Sovremennom Sostoianii Rossii, 11 Aprelia 1879-6 Aprelia 1880, 4th ed. (Saint Petersburg: Izdanie pridvornogo knigotorgovtsa K. K. Retgera, 1882), 94-97, 104, 122-124, 126, 151-152, 161-164.

126 Trukhin, "Ideia Uchreditel'nogo Sobraniia v Vozzreniiakh Liderov Revol'iutsionnoi Organizatsii 'Narodnaia Volia'," 100, 103-104; Trukhin, "Ideia Uchreditel'nogo Sobraniia vo Vzgliadakh Chlenov Revol'iutsionnoi Organizatsii ‘Narodnaia Volia' L. A. Tikhomirova i N. A. Morozova," 97.

127 M. N. Katkov, "Nasha Konstitutsiia [1882]," in Politicheskie Instituty, Izbiratel'noe Pravo i Protsess v Trudakh Rossiiskikh Myslitelei XIX-XX Vekov, eds. I. B. Borisov et al. (Moscow: Tsentral'naia izbiratel'naia komissiia Rossiiskoi Federatsii, 2008), 417; Badalian, "Polemika o Zemskom Sobore v Russkoi Presse Nachala 1880-Kh Godov," $28-31$.

128 Anan'ich and Ganelin, "S. Iu. Vitte, M. P. Dragomanov i 'Vol'noe Slovo'," 163, 169 170; Von Mohrenschildt, Toward a United States of Russia, 242.

129 O. G. Popova, "Ideia Uchreditel'nogo Sobraniia v Rossiiskoi Istorii i Ego Rol' v Popytke Sozdaniia Pravovogo Gosudarstva v 1917-Nachale 1918 G.," in Problemy Istorii Rossii, vol. 2: Opyt gosudarstvennogo stroitel'stva XV-XX Vv. (Ekaterinburg: Volot, 1998), 151.

130 I. P. Belokonskii, Zemstvo $i$ Konstitutsiia (Moscow: Mosk. knigoizd. tov-vo "Obrazovanie," 1910), 33, 41, 47, 49-52, 69, 139-141; D. B. Pavlov and V. V. Shelokhaev, eds., Rossiiskie Liberaly: Kadety i Oktiabristy: Dokumenty, 


\section{Ivan Sablin and Kuzma Kukushkin}

Vospominaniia, Publitsistika (Moscow: ROSSPEN, 1996), 41-42, 49; Teodor Shanin, Revoliutsiia Kak Moment Istiny, 1905-1907 Gg. - 1917-1922 Gg. (Moscow: Ves' mir, 1997), 57; D. B. Pavlov, O. N. Lezhneva, and V. V. Shelokhaev, eds., Liberal'noe Dvizhenie v Rossii, 1902-1905 Gg. (Moscow: ROSSPEN, 2001), 29; Lukoianov, "Perepiska A. A. Kireeva i F. D. Samarina," 12-13.

131 A. F. Zhukov, "Individual'nyi Terror v Taktike Melkoburzhuaznykh Partii v Pervoi Rossiiskoi Revoliutsii," in Neproletarskie Partii Rossii v Trekh Revoliutsiiakh: Sbornik Statei, ed. K. V. Gusev (Moscow: Nauka, 1989), 140.

132 V. V. Kriven'kii, ed., Anarkhisty: Dokumenty i Materialy 1883-1935 Gg., vol. 1: 1883-1916 Gg. (Moscow: ROSSPEN, 1998), 43-44.

133 Kriven'kii, 1: 1883-1916 gg.:71.

134 Ibid., 85-86.

135 Ibid., 108-110.

136 Quoted in Zhukov, "Individual'nyi Terror v Taktike Melkoburzhuaznykh Partii v Pervoi Rossiiskoi Revoliutsii," 142.

137 S. F. Sharapov, "Diktator: Politicheskaia Fantasia [1907]," in Izbrannoe, ed. A. V. Repnikov (Moscow: ROSSPEN, 2010), 470, 479.

138 I. A. Malinovskii, Narod $i$ Vlast' (Kiev: Izdanie gazety "Kievskie ocherki," 1905), $12-19,31$.

139 B. B. Glinskii, Bor'ba za Konstitutsiiu, 1612-1861: Istoricheskie Ocherki (Saint Petersburg: Izdanie N. P. Karabasnikova, 1908), 15-18.

140 M. V. Klochkov, Zemskie Sobory v Starinu (Saint Petersburg: Izdanie Tovarishchestva "Obshchestvennaia Pol'za," 1905), 3, 39-42, 47-48.

141 M. V. Rodzianko, "Krushenie Imperii," in Gibel' Monarkhii: Velikii Kniaz' Nikolai Mikhailovich, M. V. Rodzianko, Velikii Kniaz’ Andrei Vladimirovich, A. D. Protopopov, eds. M. Fedotova and Zvezhinskaia E. (Moscow: Fond Sergeia Dubova, 2000), 128-129.

142 Ia. A. Iakovlev, ed., Gosudarstvennoe Soveshchanie, 12-15 Avgusta 1917 Goda: Stenograficheskii Otchet (Moscow: Gosudarstvennoe izdatel'stvo, 1930), 231-232.

143 N. P. Anufriev, Dva Russkikh Uchreditel'nykh Sobraniia: Istoricheskie Paralleli (1613-1917 Gg.) (Moscow: Moskovskaia prosvetitel'naia komissiia pri Vremennom komitete Gosudarstvennoi duma, 1917), 15, 19, 20, 25-27, 31.

144 V. G. Boldyrev, Direktoriia, Kolchak, Interventy: Vospominaniia, ed. V. D. Vegman (Novonikolayevsk: Sibkraiizdat, 1925), 483-485; G. N. Sevostianov et al., eds., Delo Generala L. G. Kornilova: Materialy Chrezvychainoi Komissii Po Rassledovaniiu Dela o Byvshem Glavnokomanduiushchem Generale L. G. Kornilove i Ego Souchastnikakh, Avgust 1917 G. - Iun'1918 G., vol. 1 (Moscow: Mezhdunarodnyi fond "Demokratiia," 2003), 223, 405-406.

145 Vladimir Nabokov, Vremennoe Pravitel'stvo i Bol'shevistskii Perevorot [1921] (London: Overseas Publications Interchange, 1988), 160. See also V. Zh. Tsvetkov, Beloe Delo v Rossii, 1917-1919 Gg. (Moscow: Iauza, 2019).

146 V.Zh. Tsvetkov, Beloe Delo v Rossii, 1919 G.: Formirovanie i Evoliutsiia Politicheskikh Struktur Belogo Dvizheniia v Rossii (Moscow: Posev, 2009), 305, 348, 351, 479-480.

147 A. P. Budberg, Dnevnik Belogvardeitsa: Vospominaniia, Memuary (Minsk: Kharvest, 2001), 293; Sablin, The Rise and Fall of Russia's Far Eastern Republic, 1905-1922, 116.

148 Sablin, The Rise and Fall of Russia's Far Eastern Republic, 1905-1922, 118.

149 V. S. Zavoiko, Osnovnye Zakony Primorskoi Oblasti (Yokohama: Russkaia tipografiia, 1920).

150 Boldyrev, Direktoriia, Kolchak, Interventy, 483-485; Sablin, The Rise and Fall of Russia's Far Eastern Republic, 1905-1922, 248.

151 Ivan Sablin, "Parliaments and Parliamentarism in the Works of Soviet Dissidents, 1960s-80s," Parliaments, Estates and Representation 40, no. 1 (2020), 14, doi: 10.1080/02606755.2019.1615672. 
152 A. I. Solzhenitsyn, Kak Nam Obustroit' Rossiiu? Posil'nye Soobrazheniia (Paris: Russkaia mysl', 1990), 43-44.

153 S. I. Zabelin and A. V. Shubin, "Predlozheniia Rossiiskogo Sotsial'noEkologicheskogo Soiuza k Proektam Konstitutsii Rossii (Iiun' 1993 G.)," in Iz Istorii Sozdaniia Konstitutsii Rossiiskoi Federatsii: Konstitutsionnaia Komissiia: Stenogrammy, Materialy, Dokumenty (1990-1993 Gg.), ed. O. G. Rumiantsev, vol. 4: 1993 god, Part 2: mai-iiun' 1993 goda (Moscow: Fond konstitutsionnykh reform, 2008), 848.

154 S. P. Pykhtin, "Osnovnoi Zakon Rossii, Proekt Vnesennyi Soiuzom Vozrozhdeniia Rossii i Kongressom Russkikh Obshchin [1993]," in Iz Istorii Sozdaniia Konstitutsii Rossiiskoi Federatsii: Konstitutsionnaia Komissiia: Stenogrammy, Materialy, Dokumenty (1990-1993 Gg.), ed. O. G. Rumiantsev, vol. 5: Al'ternativnye proekty Konstitutsii Rossiiskoi Federatsii (1990-1993 Gg.) (Moscow: Fond konstitutsionnykh reform, 2009), 977, 988.

\section{Bibliography}

Aksakov, K. S. "Kratkii Istoricheskii Orcherk Zemskikh Soborov: Predislovie [Early 1850s]" [A Short Historical Overview of the Zemskii Sobors: Introduction]. In Polnoe Sobranie Sochinenii [Complete Collected Works], edited by I. S. Aksakov, 291-297. Moscow: Tipografiia P. Bakhmeteva, 1861.

- 'Zapiska 'O Vnutrennem Sostoianii Rossii,' Predstavlennaia Gosudariu Imperatoru Aleksandu II v 1855 G." [Memorandum "On the Internal State of Russia," submitted to His Imperial Majesty Alexander II in 1855]. In Russkaia Sotsial'noPoliticheskaia Mysl', 1850-1860-e Gody: Khrestomatiia [Russian Socio-Political Thought, 1850s-1860s: A Reader], edited by A. A. Shiriniants, I. Iu. Demin, A. V. Myrikova, and A. M. Rep'eva, 54-77. Moscow: Izdatel'stvo Moskovskogo universiteta, 2012.

Anan'ich, B. V., and R. Sh. Ganelin. “S. Iu. Vitte, M. P. Dragomanov i 'Vol'noe Slovo' (Po Povodu Odnogo Dokumenta iz Arkhiva M. K. Lemke)" [S. Iu Vitte, M. P. Dragomanov and Vol'noe Slovo (Based on a Document from the Archive of M. K. Lemke)]. In Trudy Leningradskogo Otdeleniia Instituta Istorii [The Works of the Leningrad Branch of the Institute of History], edited by N. E. Nosov, 7: Issledovaniia po otechestvennomu istochnikovedeniiu: Sbornik statei, posviashchennyi 75-letiiu prof. S. N. Valka [Source Studies: A Collection of Essays in Honor of Prof. S. N. Valk's 75th Birthday]:163-178. Leningrad: Nauka, 1964.

Andreev, V. E. "Semeinyi Konflikt (k Voprosu o Vzaimootnosheniiakh Imperatora Aleksandra III i Velikogo Knizia Konstantina Nikolaevicha)" [A Family Conflict (On the Question of the Relations between Emperor Alexander III and Grand Duke Konstantin Nikolaevich)]. In Aleksandr III: Pro et Contra [Alexander III: Pro et Contra], edited by I. E. Barykina and V. G. Chernukha, 435-453. Saint Petersburg: RKhGA, 2013.

Anufriev, N. P. Dva Russkikh Uchreditel'nykh Sobraniia: Istoricheskie Paralleli (1613-1917 Gg.) [Two Russian Constituent Assemblies: Historical Parallels (16131917)]. Moscow: Moskovskaia prosvetitel'naia komissiia pri Vremennom komitete Gosudarstvennoi duma, 1917.

Arinin, A. N., and V. V. Shelokhaev, eds. Prava i Svobody Cheloveka v Programmnykh Dokumentakh Osnovnykh Politicheskikh Partii i Ob"edinenii Rossii, XX Vek [Human Rights and Liberties in the Program Documents of the Main Political Parties and Associations of Russia, 20th Century]. Moscow: ROSSPEN, 2002. 
Avaliani, S. L. Zemskie Sobory: Literaturnaia Istoriia Zemskikh Soborov [Zemskii Sobors: A Literary History of the Zemskii Sobors]. Odessa: A. A. Ivasenko, 1916.

Badalian, D. A. "Polemika o Zemskom Sobore v Russkoi Presse Nachala 1880-kh Godov" [Debates on the Zemskii Sobor in the Russian Press of the Early 1880s]. Trudy SanktPeterburgskogo Gosudarstvennogo Instituta Kul'tury 201 (2013): 27-36.

—. "Poniatie 'Zemskii Sobor' i Predstavleniia o Vlasti v Rossii XIX Veka: Ot Karamzina do Stepniaka-Kravchinskogo" [The Concept 'Zemskii Sobor' and the Perceptions of Authority in Russia of the 19th Century: From Karamzin to StepniakKravchinskii]. Tetradi Po Konservatizmu, no. 4 (2018): 140-155.

Bakunin, Mikhail. "Federalism, Socialism, Anti-Theologism (1867)." In Bakunin on Anarchy: Selected Works by the Activist-Founder of World Anarchism, edited by Sam Dolgoff, 102-147. New York: Vintage Books, 1972.

Beliaev, I. D. Zemskie Sobory na Rusi (Rech' Chitannaia 12-Go Ianvaria 1867 Goda Na Torzhestvennom Akte) [Zemskii Sobors in Russia (Speech, Delivered on January 12, 1867, at a Solemn Ceremony)]. Moscow: Universitetskaia tipografiia, 1867.

Beliaev, I. V. Tsar' i Velikii Kniaz' Ioann IV Vasil'evich Groznyi, Moskovskii i Vseia Rusi [Tsar and Grand Duke Ivan IV Vasil'evich the Terrible of Moscow and Whole Russia]. Moscow: Universitetskaia tipografiia, 1866.

Belinskii, V. G. "Otvet 'Moskvitianinu' [Excerpts, 1847]” [A Response to 'Moskvitianin']. In Slavianofil'stvo: Pro et Contra [The Slavophile Movement: Pro et Contra], edited by V. A. Fateev and D. K. Burlaka, 246-257. Saint Petersburg: Izd-vo S.-Peterb. un-ta, 2009.

Belokonskii, I. P. Zemstvo i Konstitutsiia [Zemstvo and Constitution]. Moscow: Mosk. knigoizd. tov-vo "Obrazovanie," 1910.

Belokurov, S. A., ed. Utverzhdennaia Gramota ob Izbranii na Moskovskoe Gosudarstvo Mikhaila Fedorovicha Romanova [The Approved Charter on the Election of Mikhail Fedorovich Romanov to the Moscow State]. 2nd ed. Moscow: Sinoidal'naia tipografiia, 1906.

Bestuzhev-Riumin, K. N. "Slavianofil'skoe Uchenie i Ego Sud'ba v Russkoi Literature [Excerpts, 1862]" [The Slavophile Teaching and Its Destiny in Russian Literature]. In Slavianofil'stvo: Pro et Contra, edited by V. A. Fateev and D. K. Burlaka, 333-345. Saint Petersburg: Izd-vo S.-Peterb. un-ta, 2009.

Bilenky, Serhiy. Romantic Nationalism in Eastern Europe: Russian, Polish, and Ukrainian Political Imaginations. Stanford, CA: Stanford University Press, 2012.

Bogatyrev, Sergei. "Ivan IV (1533-1584)." In The Cambridge History of Russia, edited by Maureen Perrie 1: From Early Rus' to 1689, 240-63. Cambridge: Cambridge University Press, 2006.

Boldyrev, V. G. Direktoriia, Kolchak, Interventy: Vospominaniia [Directory, Kolchak, and the Interventionists: Memoirs]. Edited by V. D. Vegman. Novonikolayevsk: Sibkraiizdat, 1925.

Brown, Peter B. "The 'Zemskii Sobor' in Recent Soviet Historiography.” Russian History 10, no. 1 (1983): 77-90. doi: 10.1163/187633183X00055.

Budberg, A. P. Dnevnik Belogvardeitsa: Vospominaniia, Memuary [A White Guardsman's Diary: Recollections, Memoirs]. Minsk: Kharvest, 2001.

Cherepnin, L. V. Zemskie Sobory Russkogo Gosudarstva v XVI-XVII Vv. [Zemskii Sobors of the Russian State in the 16th-17th Century]. Moscow: Nauka, 1978.

Chernukha, V. G. “Aleksandr III (1845-1894)" [Alexander III (1845-1894)]. In Aleksandr III: Pro et Contra [Alexander III: Pro et Contra], edited by I. E. Barykina and V. G. Chernukha, 7-44. Saint Petersburg: RKhGA, 2013. 
Chicherin, B. N. O Narodnom Predstavitel'stve [On Popular Representation]. Moscow: Tipografiia Gracheva i Komp., 1866.

Davies, Brian. "Local Government Administration." In The Cambridge History of Russia, edited by Maureen Perrie 1: From early Rus' to 1689, 464-485. Cambridge: Cambridge University Press, 2006.

Dunning, Chester S. L. A Short History of Russia's First Civil War: The Time of Troubles and the Founding of the Romanov Dynasty. University Park, PA: Pennsylvania State University Press, 2001.

- Russia's First Civil War: The Time of Troubles and the Founding of the Romanov Dynasty. University Park, PA: Pennsylvania State University Press, 2010.

Ekaterina II. "Nakaz Komissii o Sostavlenii Proekta Novogo Ulozheniia [1767]" [Instruction to the Commission for Drafting the New Code]. In Konstitutsionnye Proekty $v$ Rossii XVIII - Nachala XX Veka [Constitutional Projects in Russia of the 18th-early 20th Century], edited by A. N. Medushevskii, 149-68. Moscow: ROSSPEN, 2010.

Fadeev, R. A. Pis'ma o Sovremennom Sostoianii Rossii, 11 Aprelia 1879-6 Aprelia 1880 [Letters on Russia's Current Situation, April 11, 1879-April 6, 1880]. 4th ed. Saint Petersburg: Izdanie pridvornogo knigotorgovtsa K. K. Retgera, 1882.

Galili, Z., A. Nenarokov, and L. Kheimson, eds. Men'sheviki v 1917 Godu [The Mensheviks in 1917]. Vol. 2: Ot iiul'skikh sobytii do kornilovskogo miatezha. Moscow: ProgressAkademiia, 1995.

Gerasimov, Ilya, Sergey Glebov, Jan Kusber, Marina Mogilner, and Alexander Semyonov. "New Imperial History and the Challenges of Empire." In Empire Speaks Out: Languages of Rationalization and Self-Description in the Russian Empire, edited by Ilya Gerasimov, Jan Kusber, and Alexander Semyonov, 3-32. Leiden: Brill, 2009.

Gershenzon, M. O. "Slavianofil'stvo" [The Slavophile Movement]. In Slavianofil'stvo: Pro et Contra, edited by V. A. Fateev and D. K. Burlaka, 681-688. Saint Petersburg: Izd-vo S.-Peterb. un-ta, 2009.

Gertsen, A. I. "P. A. Mart'ianov i Zemskii Tsar' [1864]" [P. A. Mart'ianov and the Zemstvo Tsar]. In Sobranie Sochinenii v Tridtsati Tomakh [Collected Works in Thirty Volumes], edited by V. P. Volgin 18:11-13, 528-529. Moscow: Izdatel'stvo Akademii nauk SSSR, 1959.

_ . "Prolegomena [1867]." In Sochineniia v Dvukh Tomakh [Collected Works in Two Volumes], edited by Z. V. Smirnova and A. I. Volodin 2, 500-525. Moscow: Mysl', 1986.

Glinskii, B. B. Bor'ba Za Konstitutsiiu, 1612-1861: Istoricheskie Ocherki [The Struggle for Constitution, 1612-1861: Historical Essays]. Saint Petersburg: Izdanie N. P. Karabasnikova, 1908.

Gloveli, G. D. "Afanasii Shchapov - Istorik Rossiiskoi Tsivilizatsii” [Afanasii Shchapov A Historian of Russian Civilization]. Federalizm 2, no. 62 (2011): 167-182.

Got'e, Iu. V., ed. Akty, Otnosiashchiesia k Istorii Zemskikh Soborov [The Acts Related to the History of the Zemskii Sobors]. Moscow: Izdanie N. N. Klochkova, 1909.

Griffits, Devid. "Zhalovannye Gramoty Ekateriny II Dvorianstvu i Gorodam 1785 Goda: O Sosloviiakh, Gramotakh, Konstitutsiiakh" [The Charters of Catherine II to the Nobility and to Towns of 1875: On the Estates, Charters, and Constitutions]. In Ekaterina II $i$ Ee Mir: Stat'i Raznykh Let [Catherine II and Her World: Articles of Different Years], edited by M. Lavrinovich and I. Fediukin, 190-250. Moscow: Novoe literaturnoe obozrenie, 2013. 


\section{Ivan Sablin and Kuzma Kukushkin}

Hellie, Richard. "Thoughts on the Absence of Elite Resistance in Muscovy." Kritika: Explorations in Russian and Eurasian History 1, no. 1 (2000): 5-20. doi: 10.1353/ kri.2008.0029.

Iakovlev, Ia. A., ed. Gosudarstvennoe Soveshchanie, 12-15 Avgusta 1917 Goda: Stenograficheskii Otchet [The State Conference, August 12-15, 1917: Verbatim Report]. Moscow: Gosudarstvennoe izdatel'stvo, 1930.

Iaroslavskaia Uchenaia Arkhivnaia Komissiia [Yaroslavl Academic Archival Committee]. Izbranie na Tsarstvo Mikhaila Feodorovicha, 1613-1913 Gg. [The Election of Mikhail Fedorovich to the Throne, 1613-1913]. Yaroslavl: Tipo-litografiia Nikolaevo zd. Snes. Monastyria, 1913.

Illarion. "Slovo o Zakone i Blagodati [Excerpts, 1030s-1050s]" [A Word on the Law and Grace]. In Russkaia Sotsial'no-Politicheskaia Mysl' XI-XVII Vv.: Khrestomatiia [Russian Soci-Political Though of the 11th-17th Century: A Reader], edited by S. V. Perevezentsev, G. V. Talina, D. V. Ermashov, A. S. Ermolina, V. S. Zubova, and A. A. Shiriniants, 24-29. Moscow: Izdatel'stvo Moskovskogo universiteta, 2011.

Kaplun, M. V. "K Voprosu o Zapadnoevropeiskikh Istokakh Pervykh Russkikh Komedii (Po Materialam Posol'skogo Prikaza Vtoroi Poloviny XVII V.)." Vestnik Tomskogo Gosudarstvennogo Universiteta 451 (2020): 28-33.

Karamzin, N. M. Istoriia Gosudarstva Rossiiskogo [The History of the Russian State]. Vol. 10. Saint Petersburg: Tipografiia N. Grecha, 1824.

—. Istoriia Gosudarstva Rossiiskogo. Vol. 12. Saint Petersburg: Tipografiia N. Grecha, 1829.

Katkov, M. N. "Nasha Konstitutsiia [1882]" [Our Constitution]. In Politicheskie Instituty, Izbiratel'noe Pravo i Protsess v Trudakh Rossiiskikh Myslitelei XIX-XX Vekov [Political Institutions, Electoral Law and Process in the Works of Russian Thinkers of the 19th-20th Century], edited by I. B. Borisov, Iu. A. Vedeneev, I. V. Zaitsev, and V. I. Lysenko, 415-417. Moscow: Tsentral'naia izbiratel'naia komissiia Rossiiskoi Federatsii, 2008.

Kavelin, K. D. "Mysli o Vybornom Nachale [1874]" [Thoughts on the Electoral Principle]. In Politicheskie Instituty, Izbiratel'noe Pravo $i$ Protsess $v$ Trudakh Rossiiskikh Myslitelei XIX-XX Vekov, edited by I. B. Borisov, Iu. A. Vedeneev, I. V. Zaitsev, and V. I. Lysenko, 362-375. Moscow: Tsentral'naia izbiratel'naia komissiia Rossiiskoi Federatsii, 2008.

Khomiakov, A. S. "Dmitrii Samozvanets: Tragediia [1833]" [Dmitrii the Impostor: A Tragedy]. In Polnoe Sobranie Sochinenii [Complete Collected Works], 3rd ed., 4:1172. Moscow: Universitetskaia tipografiia, 1900.

—. "O Starom i Novom [1839]" [On the Old and the New]. In Polnoe Sobranie Sochinenii, 3rd ed., 3:11-29. Moscow: Universitetskaia tipografiia, 1900.

__. "Opera Glinki 'Zhizn' za Tsaria' [1844]” [Glinka's Opera A Life for the Tsar]. In Polnoe Sobranie Sochinenii, 3rd ed., 3:98-103. Moscow: Universitetskaia tipografiia, 1900.

Kireev, A. A. "Slavianofil'stvo i Natsionalizm: Otvet V. S. Solov'evu [Excerpts, 1889]" [The Slavophile Movement and Nationalism: A Response to V. S. Solov'ev]. In Slavianofil'stvo: Pro et Contra, edited by V. A. Fateev and D. K. Burlaka, 513-523. Saint Petersburg: Izd-vo S.-Peterb. un-ta, 2009.

Kir'ianov, Iu. I., ed. Pravye Partii, 1905-1917 Gg.: Dokumenty i Materialy [Right-Wing Parties, 1905-1917: Documents and Materials]. Vol. 1: 1905-1910 Gg. Moscow: ROSSPEN, 1998.

, ed. Pravye Partii, 1905-1917 Gg.: Dokumenty i Materialy. Vol. 2: 1911-1917 Gg. Moscow: ROSSPEN, 1998. 
Kivelson, Valerie. Autocracy in the Provinces: The Muscovite Gentry and Political Culture in the Seventeenth Century. Stanford, CA: Stanford University Press, 1996.

- "Muscovite 'Citizenship': Rights without Freedom." The Journal of Modern History 74, no. 3 (2002): 465-489. doi: 10.1086/345109.

—. "On Words, Sources, and Historical Method: Which Truth about Muscovy?" Kritika: Explorations in Russian and Eurasian History 3, no. 3 (2002): 487-499. doi: 10.1353/kri.2002.0039.

Kliuchevskii, V. O. "Sostav Predstavitel'stva na Zemskikh Soborakh Drevnei Rusi (Posviashchaetsia B. N. Chicherinu) [1890-1892]" [The Membership of the Zemskii Sobors of Ancient Russia (Devoted to B. N. Chicherin)]. In Sochineniia [Works], edited by V. L. Ianin 8:277-374. Moscow: Mysl', 1990.

Klochkov, M. V. Zemskie Sobory v Starinu [Zemskii Sobors during the Old Times]. Saint Petersburg: Izdanie Tovarishchestva "Obshchestvennaia Pol'za," 1905.

Kollmann, Nancy Shields. By Honor Bound: State and Society in Early Modern Russia. Ithaca, NY: Cornell University Press, 1999.

Komissiia pechataniia gosudarstvennykh gramot i dogovorov, sostoiashchaia pri Moskovskom glavnom arkhive Ministerstva inostrannykh del [The Commission on Publication of State Documents and Treaties under the Main Archive of the Ministry of Foreign Affairs]. Kniga ob Izbranii na Tsarstvo Velikogo Gosudaria, Tsaria i Velikogo Kniazia Mikhaila Fedorovicha [The Book on the Election of Mikhail Fedorovich to the Throne of the Great Master, Tsar and Grand Duke]. Moscow: Sinoidal'naia tipografiia, 1856.

Kornilov, A. A. "Kurs Istorii Rossii XIX Veka [Excerpt]" [A Course of Russian History of the 19th Century]. In Aleksandr III: Pro et Contra, edited by I. E. Barykina and V. G. Chernukha, 654-695. Saint Petersburg: RKhGA, 2013.

Kriven'kii, V. V., ed. Anarkhisty: Dokumenty i Materialy 1883-1935 Gg. [Anarchists: Documents and Materials, 1883-1935] Vol. 1: 1883-1916 gg. Moscow: ROSSPEN, 1998.

Krom, M. M. Rozhdenie Gosudarstva: Moskovskaia Rus' XV-XVI Vekov [The Birth of the State: Moscow Russia of the 15th-16th Century]. Moscow: Novoe literaturnoe obozrenie, 2018.

Kurukin, I. V. Epokha “Dvorskikh Bur'”: Ocherki Politicheskoi Istorii Poslepetrovskoi Rossii, 1725-1762 Gg. [The Age of 'Court Storms': Essays on the Political History of Post-Petrine Russia, 1725-1762]. Ryazan: Chastnyi izdatel' P. A. Tribunskii, 2003.

L. L'vov [L. M. Kliachko]. Za Kulisami Starogo Rezhima: Vospominaniia Zhurnalista [Backstatge of the ancien régime: Memoirs of a Journalist]. Vol. 1. Leningrad: Gosudarstvennaia tipografiia, 1926.

L. V. Cherepnin, O. A. Derzhavina, and E. V. Kolosova, eds. Skazanie Avraamiia Palitsyna [The Tale of Avraam Palitsyn]. Moscow: Izd-vo AN SSSR, 1955.

Leontovich, V. V. Istoriia Liberlizma v Rossii, 1762-1914 [A History of Liberalism in Russia, 1762-1914]. Paris: YMCA-PRESS, 1980.

Loris-Melikov, M. T. "Doklad o Privlechenii Predstavitelei Naseleniia k Zakonosoveshchatel'noi Deiatel'nosti, 28 Ianvaria 1881 G." [Report on Attracting the Representatives of the Population to Legislation] In Konstitutsionnye Proekty $v$ Rossii XVIII - Nachala XX Veka, edited by A. N. Medushevskii, 466-472. Moscow: ROSSPEN, 2010.

Lukoianov, I. V., ed. "Perepiska A. A. Kireeva i F. D. Samarina" [The Letters between A. A. Kireev and F. D. Samarin]. Nestor, no. 3 (2000): 11-103. 


\section{Ivan Sablin and Kuzma Kukushkin}

Maier, Ingrid. "Newspaper Translations in Seventeenth-Century Muscovy: About the Sources, Topics and Periodicity of Kuranty 'Made in Stockholm' (1649).” In Explorare Necesse Est: Hyllningsskrift till Barbro Nilsson [Explorare Necesse Est: A Tribute to Barbro Nilsson], edited by Per Ambrosiani, Elisabeth Löfstrand, Laila Nordquist, and Ewa Teodorowicz-Hellman, 181-190. Stockholm: Almqvist \& Wiksell International, 2002.

Maier, Ingrid, and Stepan Shamin. "“Revolts' in the Kuranty of March-July 1671.” In From Mutual Observation to Propaganda War: Premodern Revolts in Their Transnational Representations, edited by Malte Griesse, 181-204. Bielefeld: Transcript Verlag, 2014.

Malinovskii, I. A. Narod i Vlast' [The People and the Authority]. Kiev: Izdanie gazety "Kievskie ocherki," 1905.

Mazurenko, N. N. Vserossiiskie Zemskie Sobory: Istoricheskii Ocherk [The All-Russian Zemskii Sobors: A Historical Essay]. Saint Petersburg: Tipografiia imperatorskogo chelovekoliubivogo obshchestva, 1905.

Medushevskii, A. N., ed. "Konditsii, Soderzhashchie Ogranichenie Vlasti Monarkha v Pol'zu Verkhovnogo Tainogo Soveta, 19 Ianvaria 1730 G." [The Conditions, Limiting the Authority of the Monarch in Favor of the Supreme Privy Council, January 19, 1730]. In Konstitutsionnye Proekty v Rossii XVIII - Nachala XX Veka, 76. Moscow: ROSSPEN, 2010.

Meshcheriakov, N. L., ed. Malaia Sovetskaia Entsiklopediia [The Small Soviet Encyclopedia]. Vol. 5. Moscow: Sovetskaia entsiklopediia, 1930.

Munck, Thomas. Seventeenth Century Europe 1598-1700. Macmillan: London, 1990.

Murav'ev, N. M. "Konstitutsionnyi Proekt [1825]" [Draft Constitution]. In Konstitutsionnye Proekty v Rossii XVIII - Nachala XX Veka, edited by A. N. Medushevskii, 302-22. Moscow: ROSSPEN, 2010.

. "Konstitutsiia [1825] [Constitution]." In Russkaia Sotsial'no-Politicheskaia Mysl', Pervaia Polovina XIX Veka: Khrestomatiia, edited by A. A. Shiriniants, I. Iu. Demin, A. M. Rep'eva, M. K. Kovtunenko, and A. I. Voloshin, 157-183. Moscow: Izdatel'stvo Moskovskogo universiteta, 2011.

Nabokov, Vladimir. Vremennoe Pravitel'stvo i Bol'shevistskii Perevorot [1921] [The Provisional Government and the Bolshevik Coup]. London: Overseas Press Interchange, 1988.

Nechkina, M. V., ed. “A. P. Shchapov v Gody Revoliutsionnoi Situatsii: Pis'mo k P. P. Viazemskomu Ot 8 Okriabria 1861 G." [A. P. Shchapov in the Years of Revolutionary Situation: The Letter to P. P. Viazemskii from October 8, 1861]. Literaturnoe Nasledstvo 67 (1959): 645-668.

Norberg, Jakob. “Concepts, Political.” In The Encyclopedia of Political Thought, edited by Michael T. Gibbons, Diana Coole, Elisabeth Ellis, and Kennan Ferguson 2:647-657. Malden, MA: Wiley-Blackwell, 2015.

Novosil'tsev, N. N. "Gosudarstvennaia Gramota Rossiskoi Imperill [1820]” [The State Charter of the Russian Empire]. In Konstitutsionnye Proekty v Rossii XVIII - Nachala XX Veka, edited by A. N. Medushevskii, 268-301. Moscow: ROSSPEN, 2010.

Ol'denburg, S. S. Tsarstvovanie Imperatora Nikolaia II [The Rule of Emperor Nicholas II]. Vol. 1. Belgrade: Izdanie Obshchestva Rasprostraneniia Russkoi Natsional'noi i Patrioticheskoi Literatury, 1939.

Omel'ianchuk, I. V. "Narodnoe Predstavitel'stvo v Ideologii Rossiiskikh Konservatorov Nachala XX Veka" [Popular Representation in the Ideology of Russian Conservatives of the Early 20th Century]. In Tavricheskie Chteniia 2013: Aktual'nye Problemy Parlamentarizma: IstoriiaiSovremennost': Mezhdunarodnaia Nauchnaia Konferentsiia, 
S.-Peterburg, Tavricheskii Dvoretst, 11-12 Dekabria 2013 G.: Sbornik Nauchnykh Statei [Tauride Readings 2013: The Questions of Parliamentarism: Past and Present: The International Conference, Saint Petersburg, Tauride Palace, December 11-12, 2013: A Collection of Articles], edited by A. B. Nikolaev 1:45-53. Saint Petersburg: ElekSis, 2014.

Ostrowski, Donald. "The Assembly of the Land (Zemskii Sobor) as a Representative Institution." In Modernizing Muscovy: Reform and Social Change in SeventeenthCentury Russia, edited by Jarmo Kotilaine and Marshall Poe, 111-136. London: RoutledgeCurzon, 2004.

Panin, N. I. "Proekt Manifesta o Reforme Senata i Sozdanii Imperatorskogo Soveta, 28 Dekabria 1762 G." [Draft Manifesto on the Reform of the Senate and the Creation of the Imperial Council, December 28, 1762] In Konstitutsionnye Proekty v Rossii XVIII - Nachala XX Veka, edited by A. N. Medushevskii, 135-143. Moscow: ROSSPEN, 2010.

Panov, V., and V. Lebedev, eds. "Kievskaia Letopis"” [The Kievan Chronicle]. In Drevnerusskie Letopisi, 113-245. Moscow: Academia, 1936.

Panteleev, L. F. Vospominaniia [Memoirs]. Edited by S. A. Resiner. Moscow: Gosudarstvennoe izdatel'stvo khudozhestvennoi literatury, 1958.

Pavlov, D. B., O. N. Lezhneva, and V. V. Shelokhaev, eds. Liberal'noe Dvizhenie v Rossii, 1902-1905 Gg. [The Liberal Movement in Russia, 1902-1905] Moscow: ROSSPEN, 2001.

Pavlov, D. B., and V. V. Shelokhaev, eds. Rossiiskie Liberaly: Kadety i Oktiabristy: Dokumenty, Vospominaniia, Publitsistika [Russian Liberals: Kadets and Oktiabrists: Documents, Memoirs, and Journalism]. Moscow: ROSSPEN, 1996.

Perevezentsev, S. V., G. V. Talina, D. V. Ermashov, A. S. Ermolina, V. S. Zubova, and A. A. Shiriniants, eds. "Slovo Tsaria Ivana IV Vasil'evicha na Stoglavom Sobore 1551 Goda" [The Word of Tsar Ivan IV at the Stoglav Sobor of 1551]. In Russkaia Sotsial'no-Politicheskaia Mysl' XI-XVII Vv.: Khrestomatiia, 241-242. Moscow: Izdatel'stvo Moskovskogo universiteta, 2011.

Pestel', P. I. "'Russkaia Pravda' [1825]" ['The Russian Truth']. In Konstitutsionnye Proekty v Rossii XVIII - Nachala XX Veka, edited by A. N. Medushevskii, 323-399. Moscow: ROSSPEN, 2010.

Platonov, S. F., and P. G. Vasenko. "Novyi Letopisets" [The New Chronicler], 14, Part I:23-154. Saint Petersburg: Tipografiia M. A. Aleksandrova, 1910.

Platonov, S. F. "Moskovskie Zemskie Sobory XVI i XVII Vekov [1881-1882]" [The Moscow Zemskii Sobors of the 16th and 17th Century]. In Sobranie Sochinenii [Collected Works], edited by S. O. Shmidt, V. V. Morozov, and A. V. Sirenov 1:21184. Moscow: Nauka, 2010.

Poe, Marshall. "The Truth about Muscovy." Kritika: Explorations in Russian and Eurasian History 3, no. 3 (2002): 473-486.

Pokrovskii, M. N. “Kak i Kem Pisalas' Russkaia Istoriia do Marksistov [1920]” [By Whom and How was Russian History Written before the Marxists]. In Izbrannye Proizvedeniia [Selected Works], edited by M. N. Tikhomirov, V. M. Khvostov, L. G. Beskrovnyi, and O. D. Sokolov 3:233-558. Moscow: Mysl', 1967.

_. Russkaia Istoriia [1909-1914] [Russian History]. Vol. 1. Saint Petersburg: Poligon, 2002.

Popova, O. G. “Ideia Uchreditel'nogo Sobraniia v Rossiiskoi Istorii i Ego Rol' v Popytke Sozdaniia Pravovogo Gosudarstva v 1917-Nachale 1918 G." [The Idea of the Constituent Assembly in Russian History and Its Role in the Attempt at Building a 


\section{Ivan Sablin and Kuzma Kukushkin}

State of Law] In Problemy Istorii Rossii [The Questions of Russia's History], 2: Opyt gosudarstvennogo stroitel'stva $X V-X X V v$. [The Experience of State Building of the 15th-20th Century]:146-175. Ekaterinburg: Volot, 1998.

Pozhigailo, P. A. P. A. Stolypin: Grani Talanta Politika [P. A. Stolypin: The Sides of Talent of a Politician]. Moscow: ROSSPEN, 2012.

Pykhtin, S. P. "Osnovnoi Zakon Rossii, Proekt Vnesennyi Soiuzom Vozrozhdeniia Rossii i Kongressom Russkikh Obshchin [1993]" [The Fundamental Law of Russia, A Draft submitted by the Union of Russia's Revival and the Congress of Russian Communities]. In Iz Istorii Sozdaniia Konstitutsii Rossiiskoi Federatsii: Konstitutsionnaia Komissiia: Stenogrammy, Materialy, Dokumenty (1990-1993 Gg.) [From the History of Drafting the Constitution of the Russian Federation: The Constitutional Commission: Verbatim Reports, Materials, Documents (1990-1993)], edited by O. G. Rumiantsev 5: Al'ternativnye proekty Konstitutsii Rossiiskoi Federatsii (1990-1993 Gg.) [Alternative Projects of the Constitution of the Russian Federation, 1990-1993]:966-997. Moscow: Fond konstitutsionnykh reform, 2009.

Rabow-Edling, Susanna. "The Decembrists and the Concept of a Civic Nation." Nationalities Papers 35, no. 2 (2007): 369-391.

Rodzianko, M. V. "Krushenie Imperii" [The Collapse of the Empire]. In Gibel' Monarkhii: Velikii Kniaz' Nikolai Mikhailovich, M. V. Rodzianko, Velikii Kniaz' Andrei Vladimirovich, A. D. Protopopov [The Fall of Monarchy: Grand Duke Nikolai Mikhailovich, M. V. Rodzianko, Grand Duke Andrei Vladimirovich, A. D. Protopopov], edited by M. Fedotova and E. Zvezhinskaia, 81-246. Moscow: Fond Sergeia Dubova, 2000.

Sablin, Ivan. The Rise and Fall of Russia 's Far Eastern Republic, 1905-1922: Nationalisms, Imperialisms, and Regionalisms in and after the Russian Empire. London: Routledge, 2018.

. "Parliaments and Parliamentarism in the Works of Soviet Dissidents, 1960s80s." Parliaments, Estates and Representation 40, no. 1 (2020): 78-96. doi: 10.1080/02606755.2019.1615672.

Sashalmi, Endre. "God Is High Up, The Tsar Is Far Away: The Nature of Polity and Political Culture in 17th-Century Russia." In Empowering Interactions: Political Cultures and the Emergence of the State in Europe, 1300-1900, edited by Willem Pieter Blockmans, André Holenstein, Jon Mathieu, and Daniel Schläppi, 131-148. Farnham: Ashgate, 2009.

Semyonov, Alexander. “The Real and Live Ethnographic Map of Russia': The Russian Empire in the Mirror of the State Duma." In Empire Speaks Out: Languages of Rationalization and Self-Description in the Russian Empire, edited by Ilya Gerasimov, Jan Kusber, and Alexander Semyonov, 191-228. Leiden: Brill, 2009.

Sergeevich, V. I. "Zemskie Sobory v Moskovskom Gosudarstve" [The Zemskii Sobors in the Moscow State]. In Sbornik Gosudarstvennykh Znanii [A Collection of State Studies], edited by V. P. Bezobrazov 2:1-59. Saint Petersburg: Izd. D. E. Kozhanchikova, 1875.

Sevostianov, G. N., O. K. Ivantsova, Iu. G. Orlova, K. G. Liashenko, and V. M. Khrustalev, eds. Delo Generala L. G. Kornilova: Materialy Chrezvychainoi Komissii po Rassledovaniiu Dela o Byvshem Glavnokomanduiushchem Generale L. G. Kornilove i Ego Souchastnikakh, Avgust 1917 G.-Iun' 1918 G. [The Case of General L. G. Kornilov: The Materials of the Extraordinary Commission for the Investigation of the Case of the Former Commander-in-Chief General L. G. Kornilov and His Accomplices, August 1917-June 1918] Vol. 1. Moscow: Mezhdunarodnyi fond "Demokratiia," 2003. 
Shanin, Teodor. Revoliutsiia Kak Moment Istiny, 1905-1907 Gg. - 1917-1922 Gg. [Revolution as a Moment of Truth, 1905-1907-1917-1922]. Moscow: Ves' mir, 1997. Sharapov, S. F. "Diktator: Politicheskaia Fantasia [1907]" [Dictator: A Political Fantasy]. In Izbrannoe [Selected Works], edited by A. V. Repnikov, 443-606. Moscow: ROSSPEN, 2010.

__ ' 'Rossiia Budushchego (Tret'e Izdanie ‘Opyta Russkoi Politicheskoi Programmy') [1907]" [Russia of the Future (The Third Edition of An Attempt at the Russian Political Program)]. In Izbrannoe, edited by A. V. Repnikov, 25-149. Moscow: ROSSPEN, 2010.

_. "Russkie Istoricheskie Nachala i Ikh Sovremennoe Prilozheniie [1907]" [Russian Historical Foundations and Their Contemporary Application]. In Izbrannoe, edited by A. V. Repnikov, 336-49. Moscow: ROSSPEN, 2010.

Shchapov, A. P. “Obshchii Vzgliad Na Istoriiu Velikorusskogo Naroda: Vstupitel'naia Lektsiia v Kazanskom Universitete 12 Noiabria 1860 Goda [A General View on the History of the Great Russian People: An Introductory Lecture at the Kazan University on November 12, 1860]. Edited by E. I. Chernyshev. Izvestiia Obshchestva Arkheologii, Istorii i Etnografii Pri Kazanskom Universitete 33, no. 2-3 (1926): 12-37.

. "Pis'mo Aleksandru II [1861]" [Letter to Alexander II]. Krasnyi Arkhiv 6 (19) (1926): 150-165.

Skinner, Quentin. Visions of Politics. Vol. 1: Regarding Method. Cambridge: Cambridge University Press, 2002.

Skrynnikov, R. G. Rossiia Nakanune "Smutnogo Vremeni" [Russia on the Eve of the Time of Troubles]. Moscow: Mysl', 1981.

- Ivan Groznyi [Ivan the Terrible]. Moscow: Nauka, 1983.

Solzhenitsyn, A. I. Kak Nam Obustroit' Rossiiu? Posil'nye Soobrazheniia [How Should We Rebuild Russia? Some Thoughts]. Paris: Russkaia mysl', 1990.

Speranskii, M. M. "Vvedenie k Ulozheniiu Gosudarstvennykh Zakonov [1809]" [Introduction to the Codex of State Laws]. In Konstitutsionnye Proekty v Rossii XVIIINachala XX Veka, edited by A. N. Medushevskii, 211-267. Moscow: ROSSPEN, 2010.

Stuchka, P., and N. Cheliapov, eds. "Deputat" [Deputy]. In Entsiklopediia Gosudarstva $i$ Prava [Encyclopedia of State and Law], 1:846-854. Moscow: Izdatel'stvo kommunisticheskoi akademii, 1925.

Takhtarev, K. M. Obshchestvo i Gosudarstvo i Zakon Bor'by Klassov [The Society and the State and the Law of Class Struggle]. Petrograd: Kniga, 1918.

Tarabasova, N. I., V. G. Dem'ianov, and S. I. Kotkov, eds. Vesti-Kuranty: 1645-1646, 1648 Gg. [News Columns: 1645-1646, 1648]. Moscow: Nauka, 1980.

Tarabasova, N. I., V. G. Dem'ianov, A. I. Sumkina, and S. I. Kotkov, eds. Vesti-Kuranty: 1600-1639 Gg. [News Columns: 1600-1639]. Moscow: Nauka, 1972.

Tikhomirov, L. A. "Rabochii Vopros i Russkie Idealy [1902]" [The Labor Question and the Russian Ideals]. In Konservatizm: Pro et Contra [Conservatism: Pro et Contra], edited by A. Ia. Kozhurin, A. A. Sinitsyn, and D. K. Bogatyrev, 466-499. Saint Petersburg: RKhGA, 2016.

Tiumentsev, I. O. "Iz Istorii Sozdaniia 'Istorii' Avraamiia Palitsyna” [From the History of the Making of Avraam Palitsyn's History]. In Trudy Otdela Drevnerusskoi Literatury [The Works of the Department of Ancient Russian Literature], edited by O. V. Tvorogov 57:234-247. Saint Petersburg: Dmitrii Bulanin, 2006.

Trukhin, M. D. “Ideia Uchreditel'nogo Sobraniia v Vozzreniiakh Liderov Revol'iutsionnoi Organizatsii "Narodnaia Volia"' [The Idea of the Constituent Assembly in the Views 
of the Leaders of the Revolutionary Organization People's Will]. Vestnik Moskovskogo Gosudarstvennogo Oblastnogo Universiteta: Seriia “Istoriia i Politicheskie Nauki' 5 (2012): 99-105.

—. "Ideia Uchreditel'nogo Sobraniia vo Vzgliadakh Chlenov Revol'iutsionnoi Organizatsii 'Narodnaia Volia' L. A. Tikhomirova i N. A. Morozova” [The Idea of the Constituent Assembly in the Views of the Members of the Revolutionary Organization People's Will L. A. Tikhomirov and N. A. Morozov]. Vestnik Moskovskogo Gosudarstvennogo Oblastnogo Universiteta: Seriia "Istoriia i Politicheskie Nauki," 3 (2014): 88-98.

Tsvetaev, D. V. Izbranie Mikhaila Feodorovicha Romanova na Tsarstvo [The Election of Mikhail Fedorovich Romanov to the Throne]. Moscow: T-vo skoropechatni A. A. Levenson, 1913.

Tsvetkov, V. Zh. Beloe Delo v Rossii, 1919 G.: Formirovanie i Evoliutsiia Politicheskikh Struktur Belogo Dvizheniia v Rossii [The White Cause in Russia, 1919: The Formation and the Evolution of the Political Structures of the White Movement in Russia]. Moscow: Posev, 2009.

_. Beloe Delo v Rossii, 1917-1919 Gg. [For the White Cause in Russia, 1917-1919] Moscow: Iauza, 2019.

“Ustawa Konsytuctjna Królestwa Polskiego z Dnia 27 Listopada 1815 r. [Constitution of the Kingdom of Poland, November 27, 1815]. Biblioteka Sejmowa. Accessed 19 November 2019. http://libr.sejm.gov.pl/tek01/txt/kpol/1815-r0.html.

Valuev, P. A. "Proekt Reformy Gosudarstvennogo Soveta [1863]" [The Project of the Reform of the State Council]. In Konstitutsionnye Proekty v Rossii XVIII - Nachala XX Veka, edited by A. N. Medushevskii, 408-440. Moscow: ROSSPEN, 2010.

__. "Zapiska Aleksandru II o Proekte Reformy Gosudarstvennogo Soveta, 13 Aprelia 1863 G." [Memorandum to Alexander II on the Project of the Reform of the State Council, April 13, 1863]. In Konstitutsionnye Proekty v Rossii XVIII - Nachala XX Veka, edited by A. N. Medushevskii, 400-407. Moscow: ROSSPEN, 2010.

Vavilov, S. I., K. E. Voroshilov, A. Ia. Vyshinskii, P. I. Lebedev-Polianskii, A. Lozovskii, F. N. Petrov, F. A. Rotshtein, and O. Iu. Shmidt, eds. Bol'shaia Sovetskaia Entsiklopediia [The Great Soviet Encyclopedia]. Vol. Soiuz Sovetskikh Sotsialisticheskikh Respublik. Moscow: OGIZ, 1947.

Von Mohrenschildt, Dimitri. Toward a United States of Russia: Plans and Projects of Federal Reconstruction of Russia in the Nineteenth Century. London: Associated University Presses, 1981.

Wortman, Richard S. Scenarios of Power: Myth and Ceremony in Russian Monarchy from Peter the Great to the Abdication of Nicholas II. Princeton, NJ: Princeton University Press, 2006.

Zabelin, S. I., and A. V. Shubin. "Predlozheniia Rossiiskogo Sotsial'no-Ekologicheskogo Soiuza k Proektam Konstitutsii Rossii (Iiun' 1993 G.)" [The Suggestions of the Russian Social Ecological Union to the Projects of the Constitution of Russia (June 1993)]. In Iz Istorii Sozdaniia Konstitutsii Rossiiskoi Federatsii: Konstitutsionnaia Komissiia: Stenogrammy, Materialy, Dokumenty (1990-1993 Gg.), edited by O. G. Rumiantsev 4: 1993 god, Part 2: mai-iiun' 1993 goda [May-June 1993]:837-849. Moscow: Fond konstitutsionnykh reform, 2008.

Zavoiko, V. S. Osnovnye Zakony Primorskoi Oblasti [The Fundamental Laws of the Maritime Region]. Yokohama: Russkaia tipografiia, 1920.

Zhukov, A. F. "Individual'nyi Terror v Taktike Melkoburzhuaznykh Partii v Pervoi Rossiiskoi Revoliutsii" [Individual Terror in the Tactics of the Petty Bourgeois 
Parties during the First Russian Revolution]. In Neproletarskie Partii Rossii v Trekh Revoliutsiiakh: Sbornik Statei [Non-Proletarian Parties of Russia in Three Revolutions: A Collection of Articles], edited by K. V. Gusev, 138-144. Moscow: Nauka, 1989.

Zimin, A. A. Oprichnina Ivana Groznogo [The Oprichnina of Ivan the Terrible]. Moscow: Mysl', 1964. 